\title{
A Functional Switch in Tonic GABA Currents Alters the Output of Central Amygdala Corticotropin Releasing Factor Receptor-1 Neurons Following Chronic Ethanol Exposure
}

\author{
Melissa A. Herman, ${ }^{-C a n d i c e ~ C o n t e t, ~ a n d ~ M a r i s a ~ R o b e r t o ~}$ \\ Committee on the Neurobiology of Addictive Disorders, The Scripps Research Institute, La Jolla, California 92037
}

The corticotropin releasing factor (CRF) system in the central amygdala (CeA) has been implicated in the effects of acute ethanol and the development of alcohol dependence. We previously demonstrated that CRF receptor 1 (CRF1) neurons comprise a specific component of the CeA microcircuitry that is selectively engaged by acute ethanol. To investigate the impact of chronic ethanol exposure on inhibitory signaling in CRF1+ CeA neurons, we used CRF1:GFP mice subjected to chronic intermittent ethanol (CIE) inhalation and examined changes in local inhibitory control, the effects of acute ethanol, and the output of these neurons from the CeA. Following CIE, CRF1+ neurons displayed decreased phasic inhibition and a complete loss of tonic inhibition that persisted into withdrawal. CRF1 - neurons showed a cell type-specific upregulation of both phasic and tonic signaling with CIE, the latter of which persists into withdrawal and is likely mediated by $\delta$ subunitcontaining $\mathrm{GABA}_{\mathrm{A}}$ receptors. The loss of tonic inhibition with CIE was seen in CRF1 + and CRF1 - neurons that project out of the CeA and into the bed nucleus of the stria terminalis. CRF1+ projection neurons displayed an increased baseline firing rate and loss of sensitivity to acute ethanol following CIE. These data demonstrate that chronic ethanol exposure produces profound and long-lasting changes in local inhibitory control of the CeA, resulting in an increase in the output of the CeA and the CRF1 receptor system, in particular. These cellular changes could underlie the behavioral manifestations of alcohol dependence and potentially contribute to the pathology of addiction.

Key words: alcohol; amygdala; CRF; CRF1; GABA; tonic

\section{Significance Statement}

The corticotropin releasing factor (CRF) system in the central amygdala (CeA) has been implicated in the effects of acute and chronic ethanol. We showed previously that CRF receptor 1-expressing (CRF1+) neurons in the CeA are under tonic inhibitory control and are differentially regulated by acute ethanol (Herman et al., 2013). Here we show that the inhibitory control of CRF1+ CeA neurons is lost with chronic ethanol exposure, likely by a functional switch in local tonic signaling. The loss of tonic inhibition is seen in CRF1 + projection neurons, suggesting that a critical consequence of chronic ethanol exposure is an increase in the output of the CeA CRF1 system, a neuroadaptation that may contribute to the behavioral consequences of alcohol dependence.

\section{Introduction}

Alcohol dependence is a complex clinical disorder characterized by repeating cycles of intake and withdrawal and a behavioral phenotype that includes the loss of control over consumption and impaired social functioning (Hoffman and Tabakoff, 1996;

\footnotetext{
Received April 15, 2016; revised July 27, 2016; accepted Aug. 10, 2016.

Author contributions: M.A.H., C.C., and M.R. designed research; M.A.H. performed research; C.C. contributed unpublished reagents/analytic tools; M.A.H. analyzed data; M.A.H., C.C., and M.R. wrote the paper.

This work was supported by the Pearson Center for Alcoholism and Addiction Research, the Clayton Medical Research Foundation, and NIAAA Grants AA021491, AA023002, AA015566, AA06420, AA017447, AA020913, and AA024198. This is manuscript \#29330 from the Scripps Research Institute. We thank Nicholas Justice at the University of Texas Health Science Center at Houston for providing CRF1:GFP breeders.

The authors declare no competing financial interests.

Correspondence should be addressed to Dr. Melissa A. Herman, The Scripps Research Institute, 10550 North Torrey Pines Road, La Jolla, CA 92037. E-mail: mherman@scripps.edu.

DOI:10.1523/JNEUROSCI.1267-16.2016

Copyright $\odot 2016$ the authors $\quad 0270-6474 / 16 / 3610729-13 \$ 15.00 / 0$
}

Eckardt et al., 1998). These behaviors appear to be mediated by adaptations at the cellular level as the brain attempts to overcome the effects of alcohol intake. The central nucleus of the amygdala (CeA) is a component of the extended amygdala, a macrostructure that mediates the negative reinforcing properties of alcohol and drugs of abuse (Alheid and Heimer, 1988). The CeA receives multiple inputs from a number of brain regions and acts as an integrative hub that has been implicated in stress, anxiety, and alcohol use disorders (Gilpin et al., 2015). The CeA is primarily composed of GABA neurons that synapse locally as well as project out of the CeA to regulate the flow of information to downstream brain regions, such as the bed nucleus of the stria terminalis (BNST). Local inhibitory control of CeA neurons includes both phasic and tonic inhibition, both of which are selectively sensitive to the effects of acute ethanol (EtOH; Roberto et al., 2003; Herman et al., 2013). Previous work has identified neuroadaptations 
in phasic signaling in the CeA following chronic ethanol (Roberto et al., 2004) and in tonic signaling in the rat (Herman and Roberto, 2016), but no studies have used mouse models to selectively examine the changes in tonic conductance in specific components of CeA circuitry.

The transition to alcohol dependence is associated with the recruitment of brain stress systems, most notably the corticotropin releasing factor (CRF) system (Heilig and Koob, 2007). Chronic ethanol exposure and withdrawal is associated with an upregulation of the CRF system in rats (Funk et al., 2007; Roberto et al., 2010) and mice (Eisenhardt et al., 2015). Notably, increased ethanol intake by dependent rats and mice can be reversed by a CRF1 antagonist (Chu et al., 2007; Finn et al., 2007; Funk et al., 2007; Correia et al., 2015), suggesting a critical role of the CRF1 system in the behavioral expression of alcohol dependence. CRF in the CeA has been implicated in the effects of acute ethanol on phasic GABA transmission in naive mice (Nie et al., 2004), after early binge-like ethanol drinking (Lowery-Gionta et al., 2012), and in alterations in GABA transmission in naive and dependent rats (Roberto et al., 2010). However, the impact of chronic ethanol on tonic GABA transmission and CRF1 signaling within the CeA remains unexamined. We showed previously that CRF1expressing $(\mathrm{CRF} 1+)$ neurons make up a distinct component of CeA circuitry that is differentially regulated by acute ethanol. CRF1+ neurons are not directly activated by acute ethanol, but instead are engaged via a local microcircuit involving increased inhibition at local CRF1- interneurons that synapse onto CRF1+ neurons (Herman et al., 2013). Based on our previous work on the CRF1 receptor circuitry in the CeA, and the relative sensitivity of specific components of CeA circuitry to acute ethanol, we hypothesized that chronic ethanol exposure would result in significant neuroadaptations in tonic signaling in CRF1 + CeA neurons and that these changes would impact excitability and subsequent output of the CeA network. We used transgenic mice expressing green fluorescent protein (GFP) in CRF1+ neurons to examine the effects of chronic ethanol exposure on (1) inhibitory signaling (phasic and tonic) in CRF1+ CeA neurons, (2) inhibitory signaling (phasic and tonic) in CRF1 - CeA neurons, and (3) the excitability of CeA projection neurons and the sensitivity of these neurons to acute ethanol to determine the impact on CeA output to downstream targets in the extended amygdala.

\section{Materials and Methods}

Brain slice preparation. All procedures were approved by the Scripps Research Institutional Animal Care and Use Committee and were consistent with the National Institutes of Health Guide for the Care and Use of Laboratory Animals. We prepared slices from 58 CRF1:GFP transgenic adult male mice (2-6 months, $18-30 \mathrm{~g}$ ) that express GFP under the control of the promoter of the CRF1 receptor gene (Crhr1). These mice were generated using bacterial artificial chromosome recombination techniques such that the first exon of Crhrl was replaced with the sequence encoding GFP. For a detailed description of the transgene design and histological validation of these mice, see Justice et al. (2008).

Mice were subjected to brief anesthesia ( $3-5 \%$ isoflurane) followed by rapid decapitation and removal of the brain to an ice-cold high-sucrose solution, $\mathrm{pH} 7.3-7.4$, that contained the following (in $\mathrm{mM}$ ): 206 sucrose, $2.5 \mathrm{KCl}, 0.5 \mathrm{CaCl}_{2}, 7.0 \mathrm{MgCl}_{2}, 1.2 \mathrm{NaH}_{2} \mathrm{PO}_{4}, 26 \mathrm{NaHCO}_{3}, 5.0$ glucose, and 5 HEPES. Brains were cut into transverse sections $(300-400$ $\mu \mathrm{m}$ ) on a vibrating microtome (Leica VT1000S) and placed in an oxygenated $\left(95 \% \mathrm{O}_{2} / 5 \% \mathrm{CO}_{2}\right.$ ) artificial CSF (ACSF) solution composed of the following (in mM): $130 \mathrm{NaCl}, 3.5 \mathrm{KCl}, 1.25 \mathrm{NaH}_{2} \mathrm{PO}_{4}, 1.5 \mathrm{MgSO}_{4} \cdot 7$ $\mathrm{H}_{2} \mathrm{O}, 2.0 \mathrm{CaCl}_{2}, 24 \mathrm{NaHCO}_{3}$, and 10 glucose. Slices were incubated in this solution for $30 \mathrm{~min}$ at $35-37^{\circ} \mathrm{C}$, followed by $30 \mathrm{~min}$ equilibration at room temperature $\left(21-22^{\circ} \mathrm{C}\right)$. Following equilibration, a single slice was transferred to a recording chamber mounted on the stage of an upright microscope (Olympus BX50WI).

Electrophysiological recording. We visualized neurons using infrared differential interference contrast (IR-DIC) optics and an EXi Aqua camera (QImaging). A $60 \times$ magnification water-immersion objective (Olympus) was used for identifying and approaching neurons. To avoid photolytic damage, initial exposure to episcopic fluorescence illumination was brief $(<2 \mathrm{~s})$. We detected fluorescent neurons using an X-Cite $120 \mathrm{Q}$ fluorescent illumination system (Lumen Dynamics) and captured images using QCapture software (QImaging). We made whole-cell (voltage-clamp and current-clamp) and juxtacellular (cell-attached) recordings with patch pipettes (3-5 $\mathrm{M} \Omega$; King Precision Glass) coupled to a Multiclamp 700B amplifier (Molecular Devices), low-pass filtered at 2-5 kHz, digitized (Digidata 1440A; Molecular Devices), and stored on a computer using pClamp 10 software (Molecular Devices). All recordings were performed at room temperature. Series resistance was typically $<10$ $\mathrm{M} \Omega$ and was continuously monitored with a hyperpolarizing $10 \mathrm{mV}$ pulse. Electrophysiological properties of cells were determined by pClamp 10 Clampex software online during voltage-clamp recording using a $5 \mathrm{mV}$ pulse delivered after breaking into the cell. The resting membrane potential was determined online after breaking into the cell using the zero current $(I=0)$ recording configuration, and the liquid junction potential was included in the determination.

The intracellular solution used for voltage- and current-clamp recordings was composed of the following (in mM): $145 \mathrm{KCl}, 5 \mathrm{EGTA}, 5 \mathrm{MgCl}_{2}$, 10 HEPES, $2 \mathrm{Na}$-ATP, and $0.2 \mathrm{Na}-\mathrm{GTP}$. The pipette solution for juxtacellular (cell-attached) recordings was ACSF. Drugs were dissolved in ACSF and applied either by Y-tubing application for local perfusion primarily on the neuron of interest or by bath perfusion. To isolate the inhibitory currents mediated by $\mathrm{GABA}_{\mathrm{A}}$ receptors, all recordings (voltage-clamp and cell-attached) were performed in the presence of the glutamate receptor blockers 6,7-dinitroquinoxaline-2,3-dione (DNQX; 20 $\mu \mathrm{M})$ and DL-2-amino-5-phosphonovalerate (AP-5; $50 \mu \mathrm{M})$ and the $\mathrm{GABA}_{\mathrm{B}}$ receptor antagonist (2S)-3-[[(1S)-1-(3,4-Dichlorophenyl)ethyl] amino-2-hydroxypropyl] (phenylmethyl)phosphinic acid hydrochloride CGP55845A (1 $\mu \mathrm{M})$. All voltage-clamp and cell-attached recordings were performed in a gap-free acquisition mode with a sampling rate per signal of $10 \mathrm{kHz}$ or a total data throughput equal to $20 \mathrm{kHz}(2.29 \mathrm{MB} / \mathrm{min})$. All current-clamp recordings were performed in sweeps with a sampling rate per signal of $10 \mathrm{kHz}$ or a total data throughput equal to $20 \mathrm{kHz}(2.29$ $\mathrm{MB} / \mathrm{min}$ ) as defined by pClamp 10 Clampex software.

Chronic intermittent ethanol vapor inhalation. Seven independent cohorts including 30 adult male CRF1:GFP mice were housed in ethanol inhalation chambers (La Jolla Alcohol Research) and exposed to chronic intermittent ethanol (CIE) vapor ( $16 \mathrm{~h}$ ) followed by air $(8 \mathrm{~h}) 4 \mathrm{~d}$ per week for a period of $4-5$ weeks. Before each vapor exposure, CIE mice were injected intraperitoneally with a solution of ethanol $(1.5 \mathrm{~g} / \mathrm{kg})$ and pyrazole ( $1 \mathrm{mmol} / \mathrm{kg}$; Sigma), an alcohol dehydrogenase inhibitor, to initiate intoxication and maintain constant blood alcohol levels (BALs). Control mice ( $n=28$, air) were exposed to room air and received an injection of pyrazole $(1 \mathrm{mmol} / \mathrm{kg})$ at the onset of each ethanol vapor exposure. Ethanol drip rate and air flow were adjusted so as to yield BALs averaging $150-275 \mathrm{mg} / \mathrm{dl}$, as determined by regular tail bleedings (one to two times per week). BALs were measured using an Analox GM7 analyzer. Terminal BALs were also determined at the time of death when mice were euthanized immediately after their last ethanol vapor exposure (CIE mice) and averaged $266.6 \pm 15.4 \mathrm{mg} \%$. Another group of mice underwent 3-7 d of withdrawal after their last vapor exposure before being euthanized (CIE-WD mice). Air-exposed counterparts were generated for both CIE and CIE-WD groups (i.e., killed $16 \mathrm{~h}$ or $4-8 \mathrm{~d}$ after their last pyrazole injection, respectively). No statistically significant difference was observed between these two control groups, so data were pooled into a single control group, designated air control (AIR).

Retrograde labeling of CeA neurons. Adult male mice $(n=14), 3-4$ months of age (21-28 g), were anesthetized with a $1-3 \%$ isoflurane/ oxygen mixture, placed on a warming pad, and mounted in a stereotaxic frame (David Kopf Instruments). A vertical incision was made in the skin overlaying the skull, which was subsequently exposed and cleaned. Head placement was adjusted to a level skull position according to bregma and 

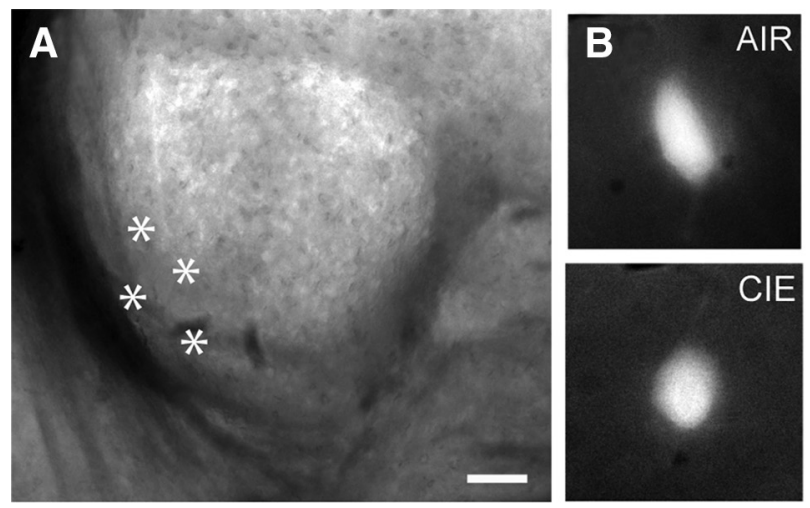

C

Low Threshold Bursting

Regular Spiking

Late Spiking
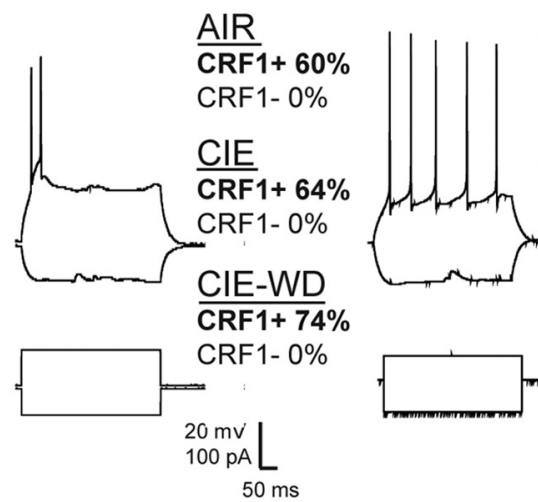

AIR

CRF $1+40 \%$

CRF $1-41 \%$

AIR

CIE

$\overline{\mathrm{CRF}} 1+36 \%$ UU $\frac{\mathrm{CIE}}{\mathrm{CRF} 1}+0 \%$

CRF1- $39 \%$

CIE-WD
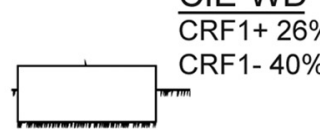

CRF1- $40 \%$

$20 \mathrm{mV}$

$100 \mathrm{pA} L$

$50 \mathrm{~ms}$

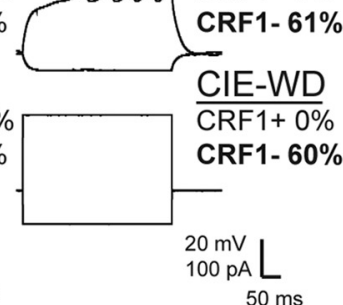

\begin{tabular}{|l|l|l|l|l|}
\hline $\mathbf{D}$ & $\begin{array}{l}\text { Membrane } \\
\text { Capacitance } \\
\mathrm{Cm}(\mathrm{pF})\end{array}$ & $\begin{array}{l}\text { Membrane } \\
\text { Resistance } \\
\mathrm{Rm}(\mathrm{M} \Omega)\end{array}$ & $\begin{array}{l}\text { Time } \\
\text { Constant } \\
\text { Tau }(\mathrm{ms})\end{array}$ & $\begin{array}{l}\text { Membrane } \\
\text { Potential } \\
\text { Vm }(\mathrm{mV})\end{array}$ \\
\hline Air CRF1+ & $39.6 \pm 2.5^{\star}$ & $279.5 \pm 25.5$ & $445.8 \pm 49.8^{*}$ & $-53.6 \pm 2.0$ \\
\hline Air CRF1- & $50.6 \pm 5.0$ & $305.2 \pm 41.3$ & $641.2 \pm 91.6$ & $-54.6 \pm 2.6$ \\
\hline CIE CRF1+ & $40.9 \pm 3.9^{*}$ & $239.7 \pm 27.7$ & $445.1 \pm 66.1^{*}$ & $-49.0 \pm 5.7$ \\
\hline CIE CRF1- & $65.6 \pm 4.8$ & $207.4 \pm 14.8$ & $750.1 \pm 69.6$ & $-58.2 \pm 2.0$ \\
\hline CIE-WD CRF1+ & $38.8 \pm 2.5^{*}$ & $258.3 \pm 26.1$ & $415.2 \pm 51.7^{*}$ & $-53.1 \pm 1.8$ \\
\hline CIE-WD CRF1- & $59.2 \pm 5.9$ & $238.4 \pm 28.2$ & $613.6 \pm 66.3$ & $-55.8 \pm 2.7$ \\
\hline
\end{tabular}

${ }^{*} \mathrm{p}<0.05$ as compared to CRF1-

Figure 1. A, A $10 \times$ magnification photomicrograph of a coronal CeA slice indicating recording sites of CRF1+ neurons (asterisks) and anatomical location (bregma, $-1.46 \mathrm{~mm}$ ). B, A $60 \times$ magnification of a CRF1 + CeA neuron from an AIR mouse (top) and a CIE mouse (bottom) using fluorescent optics (left) and IR-DIC optics (right). C, Representative current-clamp recordings of CeA cell types and the proportions of CRF1 + and CRF1 - neurons of each cell type in AIR, CIE, and CIE-WD groups for lowthreshold bursting (left), regular-spiking (middle), and late-spiking neurons (right). D, Summary of membrane characteristics (CRF1+ AIR, $n=34 ;$ CRF1-AIR, $n=23 ;$ CRF1+ CIE, $n=20 ;$ CRF1-CIE, $n=34 ;$ CRF1+ CIE-WD,$n=25 ;$ CRF1-CIE-WD,$n=$ 31). ${ }^{*} p<0.05$ by unpaired $t$ test comparing CRF1+ to CRF1 - in each group. Scale bars: $A, 100 \mu \mathrm{m} ; \boldsymbol{B}, 20 \mu \mathrm{m}$.

lambda coordinates. A small hole was drilled over the target brain site [dorsal lateral BNST (dlBNST), AP, $0.0 \mathrm{~mm}$; ML, $\pm 1.1 \mathrm{~mm}$; DV, -4.3 $\mathrm{mm}$ ] based on the atlas of Franklin and Paxinos (2008). Bilateral 30 -gauge stainless-steel injector needles connected to Tygon tubing preloaded with fluorescent microspheres (Lumafluor; 530/590 nm excitation/emission) were lowered to the dorsal lateral BNST. We injected a volume of $\sim 100 \mathrm{nl}$ of undiluted fluorescent microspheres suspension over a 1-2 min period using a Hamilton microsyringe controlled by a pump (Harvard Apparatus). The injector needles were left in place for an additional $10 \mathrm{~min}$ to minimize backflow up the needle track, after which injector needles were removed and the scalp incision was closed. Mice were allowed to recover from surgery for 1 week before beginning chronic intermittent ethanol vapor inhalation.

Drugs and chemicals. We purchased DNQX, AP-5, and CGP55845A (1 $\mu \mathrm{M}$ ) from Tocris Bioscience. We purchased SR-95531 [gabazine (GBZ); 100
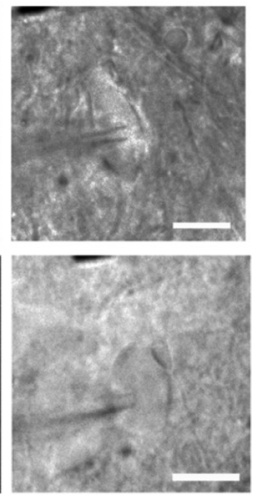

CRF1- $59 \%$

$\mu \mathrm{M}]$ and 4,5,6,7-tetrahydroisoxazolo[5,4-c]pyridin-3-ol (THIP; $5 \mu \mathrm{M}$ ) from Sigma.

Statistical analysis. Frequency, amplitude, and decay of IPSCs were analyzed and visually confirmed using a semiautomated thresholdbased mini detection software (Mini Analysis, Synaptosoft). We determined averages of IPSC characteristics from baseline and experimental drug conditions containing a minimum of 60 events (time period of analysis varied as a product of individual event frequency), and we determined decay kinetics using exponential curve fittings and reported them as decay time (in milliseconds). All detected events were used for event frequency analysis, but superimposed events were eliminated for amplitude and decay kinetic analysis. In voltage-clamp recordings, we determined tonic currents using Clampfit 10.2 (Molecular Devices) and a previously described method (Glykys and Mody, 2007b) in which the mean holding current (i.e., the current required to maintain the $-60 \mathrm{mV}$ membrane potential) was obtained by a Gaussian fit to an all-points histogram over a $5 \mathrm{~s}$ interval. The all-points histogram was constrained to eliminate the contribution of IPSCs to the holding current. We quantified responses as the difference in holding current between baseline and experimental conditions. The frequency of firing discharge in cellattached recordings was evaluated using threshold-based event detection analysis in Clampfit 10.2 (Molecular Devices). Events were analyzed for independent significance using a one-sample $t$ test and compared using a twotailed $t$ test for independent samples, a paired two-tailed $t$ test for comparisons made within the same recording, a one-way ANOVA with a Bonferroni post hoc analysis for comparisons made between three or more groups, or a two-way ANOVA with a Bonferroni post hoc analysis for comparisons between there or more groups and multiple independent variables. All statistical analyses were performed using Prism 5.02 (GraphPad). Data are presented as mean \pm SE. In all cases, $p<0.05$ was the criterion for statistical significance.

\section{Results}

Differential membrane properties of CRF1 + and CRF1 - CeA neurons are not affected by CIE exposure

GFP-positive CRF1-containing (CRF1+) neurons were identified and differentiated from unlabeled CeA neurons (CRF1-), as described previously (Herman et al., 2013). A coronal section of the CeA with representative sites of CRF1+ neurons detected during live-slice recording is shown in Figure $1 A$ (asterisks). Figure $1 B$ shows CRF1+ CeA neurons from airexposed, pyrazole-injected control mice (AIR, top) and CIE vapor-exposed mice (bottom) visualized using fluorescent optics (left) and IR-DIC optics (right). CeA neurons were cell typed according to firing properties, as described previously (Chieng et al., 2006; Herman et al., 2013). The majority of CRF1+ neurons were of the low-threshold bursting (LTB) type (Fig. 1C, left), and a smaller proportion were of the regular-spiking (RS) type (Fig. $1 C$, middle). CRF1 - neurons were divided into the late-spiking (LS) type (Fig. 1C, right) and the RS type (Fig. 1C, middle). 
A

CRF1+

AIR

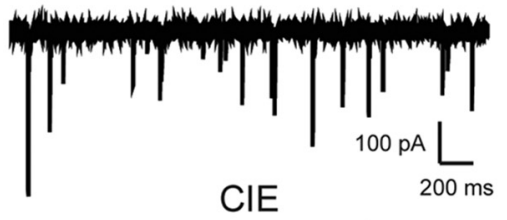

CIE

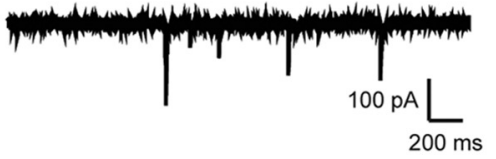

CIE-WD

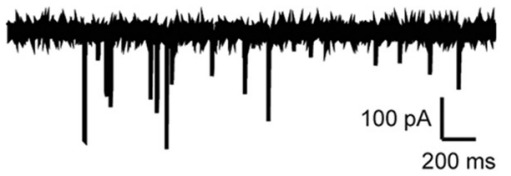

C CRF1+

Low Threshold Bursting
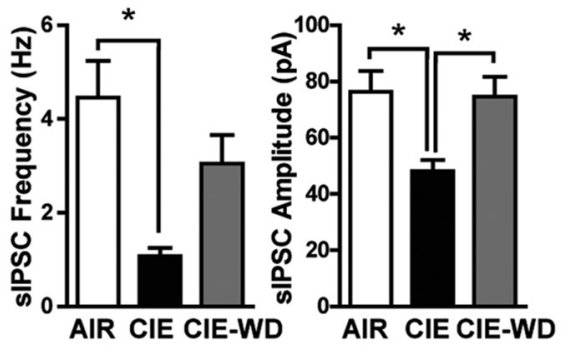

E

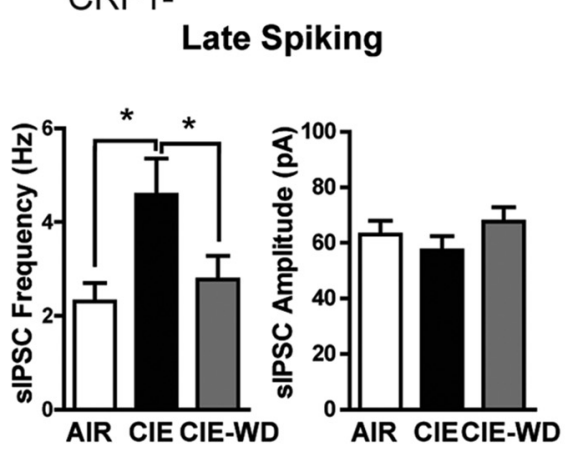

G CRF1+

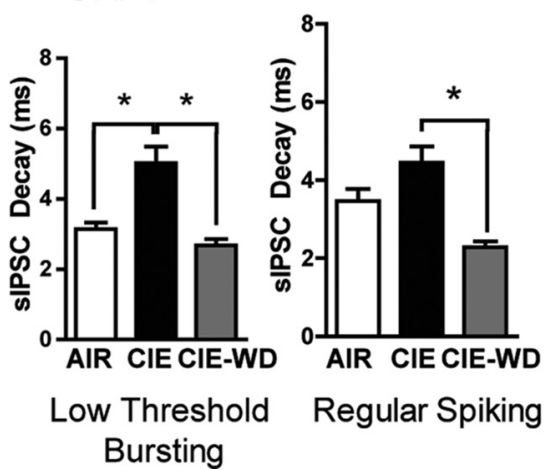

B CRF1-

AIR

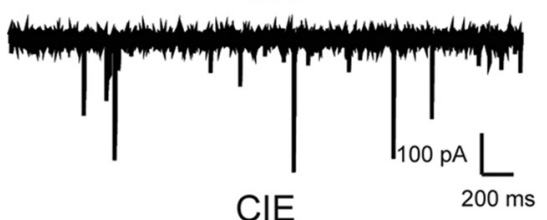

CIE-WD

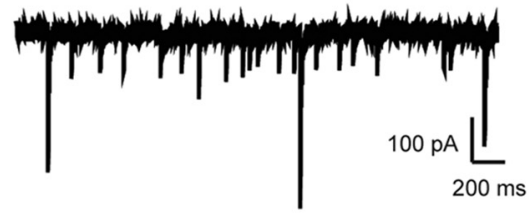

D CRF1+

\section{Regular Spiking}

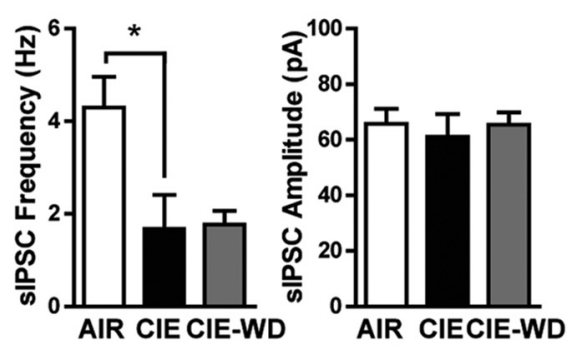

F CRF1-
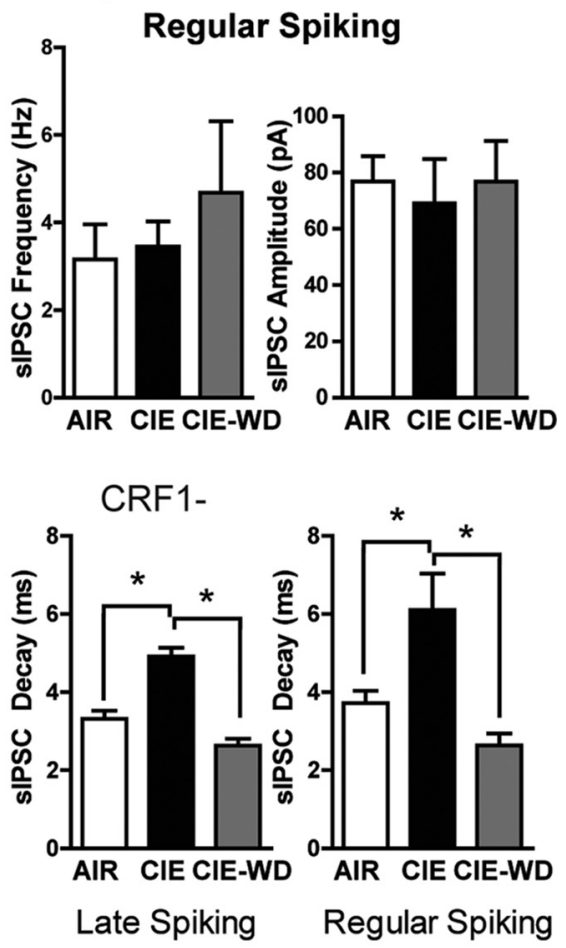

Importantly, the relative distribution of the cell types was not significantly different between AIR, CIE, and CIE followed by 3-7 d of withdrawal (CIE-WD) groups. Consistent with our previous report (Herman et al., 2013), CRF1+ neurons displayed a significantly smaller membrane capacitance $\left(C_{\mathrm{m}}\right)$ and lower time constant (tau) compared to CRF1- neurons, and this difference was consistent between AIR, CIE, and CIE-WD groups $(p<0.05$ comparing CRF1+ and CRF1 - in each group; Fig. $1 D$; AIR CRF1,$+ n=34$; AIR CRF $1-, n=23$; CIE CRF1,$+ n=25$; CIE CRF1,$- n=31$; CIE-WD CRF1,$+ n=$ 29; CIE-WD CRF1-, $n=35$ ).

Baseline phasic inhibitory transmission is altered in CRF1 + CeA neurons after CIE

Baseline phasic $\mathrm{GABA}_{\mathrm{A}}$ receptor activity was assessed using whole-cell voltageclamp recordings of spontaneous IPSCs (sIPSCs). LTB CRF1+ neurons displayed a significantly lower baseline sIPSC frequency and amplitude after CIE (1.1 \pm $0.2 \mathrm{~Hz}, 48.1 \pm 4.1$ pA; $n=18$; Fig. $2 A, C)$ compared to AIR $(4.5 \pm 0.8 \mathrm{~Hz}, 76.3 \pm$ 7.4 pA; $n=21 ; p<0.05$; Fig. $2 A, C)$. The decrease in sIPSC frequency was partially reversed and the decrease in sIPSC amplitude was completely reversed following withdrawal $(3.0 \pm 0.6 \mathrm{~Hz}, 74.6 \pm 7.1 \mathrm{pA}$; $n=17$; $p<0.05$; Fig. $2 A, C)$. RS CRF1+ neurons also displayed a significantly lower baseline sIPSC frequency after CIE $(1.7 \pm 0.7 \mathrm{~Hz} ; n=10$; Fig. $2 D)$ compared to $\operatorname{AIR}(4.3 \pm 0.7 \mathrm{~Hz} ; n=13 ; p<0.05$; Fig. $2 D$ ), but the decrease persisted into

Figure 2. A, Representative voltage-clamp recordings of baseline sIPSCS from a CRF1+ neuron from an AIR mouse (top), a CIE mouse (middle), and a (IE-WD mouse (bottom). $\boldsymbol{B}$, Representative voltage-clamp recordings of baseline sIPSCS from a CRF1 - neuron from an AIR mouse (top), a CIE mouse (middle), and a CIE-WD mouse (bottom). C, Summary of sIPSC frequency (left) and amplitude (right) in LTB CRF1+ neurons from AIR, CIE, and CIE-WD mice (AIR, $n=21$; CIE, $n=18$; (IE-WD, $n=17$ ). $\boldsymbol{D}$, Summary of sIPSC frequency (left) and amplitude (right) in regular-spiking CRF1 + neurons from AIR, CIE, and CIE-WD mice (AIR, $n=13$; CIE, $n=10$; CIE-WD, $n=$ 6). $E$, Summary of sIPSC frequency (left) and amplitude (right) in late-spiking CRF1- neurons from AIR, CIE, and CIE-WD mice (AIR, $n=18$; (IE, $n=12$; (IE-WD, $n=16$ ). $\boldsymbol{F}$, Summary of sIPSC frequency (left) and amplitude (right) in regularspiking CRF1 - neurons from AIR, CIE, and CIE-WD mice (AIR, $n=13 ;(\mathrm{IE}, n=12$; (IE-WD, $n=8)$. G, Summary of the sIPSC decay in $\mathrm{LTB}$ (AIR, $n=21$; (IE, $n=18$; (IE-WD, $n=17$ ) and regular-spiking (AIR, $n=13$; (IE, $n=10$; (IE-WD, $n=6$ ) CRF1+ neurons (left) and late-spiking (AIR, $n=18 ;$ C (IE, $n=$ 12 ; (IE-WD, $n=16$ ) and regular-spiking (AIR, $n=13$; CIE, $n=12$; (IE-WD, $n=8)$ CRF $1-$ neurons (right). ${ }^{*} p<0.05$ by one-way ANOVA. 
withdrawal $(1.8 \pm 0.3 \mathrm{~Hz} ; n=6$; Fig. $2 D)$. No change in sIPSC amplitude was observed in RS CRF1+ neurons after CIE or CIE-WD (Fig. 2D). In contrast to what was observed in CRF1+ neurons, CRF1 - neurons displayed cell-type specific changes in sIPSC frequency. LS CRF1- neurons displayed a significantly higher baseline sIPSC frequency after CIE $(4.6 \pm 0.8 \mathrm{~Hz} ; n=12$; Fig. $2 B, E)$ compared to AIR $(2.3 \pm 0.4 \mathrm{~Hz} ; n=18$; $p<0.05$; Fig. $2 B, E)$, and the increase was reversed by withdrawal $(2.7 \pm 0.5$ $\mathrm{Hz} ; n=16 ; p<0.05$; Fig. $2 B, E)$. No change in sIPSC amplitude was observed in LS CRF1 - neurons after CIE or CIE-WD (Fig. $2 E$ ). RS CRF1 - neurons displayed no change in sIPSC frequency or amplitude after CIE or CIE-WD (Fig. 2F). Changes in sIPSC kinetics were also observed in both CRF1+ and CRF1 - neurons following CIE and CIE-WD. LTB CRF1+ neurons displayed a small but significant reduction in rise time between the CIE and CIE-WD $(2.0 \pm 0.2$ and $1.4 \pm 0.2 \mathrm{~ms}$, respectively; CIE, $n=18$; CIE-WD, $n=17 ; p<0.05)$. LS CRF1- neurons displayed a similar reduction in rise time between CIE and CIE-WD (2.0 \pm 0.1 and $1.4 \pm 0.1 \mathrm{~ms}$, respectively; CIE, $n=19$; CIE-WD, $n=12$; $p<0.05)$, and RS CRF1 - neurons displayed a significant increase in rise time between AIR and CIE $(1.4 \pm 0.1$ and $2.1 \pm 0.1$ ms, respectively; AIR, $n=13$; CIE, $n=12$; $p<0.05)$. Notably, CIE produced an increase in the decay time of all cell types $(\mathrm{CRF} 1+$ and $\mathrm{CRF} 1-)$ that was reversed in CIE-WD $(p<0.05$; Fig. $2 G)$.

\section{Tonic inhibitory transmission is selectively altered in CRF1+ and late-spiking CRF1 - CeA neurons after CIE, and this alteration persists into withdrawal}

As we reported previously that the tonic conductance in CRF1+ neurons was driven by GABA release (Herman et al., 2013), we hypothesized that the decrease in phasic inhibition in CRF1+ neurons following CIE may also have consequences for tonic conductance. Baseline tonic $\mathrm{GABA}_{\mathrm{A}}$ receptor activity was assessed using whole-cell voltage-clamp recordings and the $\mathrm{GABA}_{\mathrm{A}}$ receptor antagonist gabazine. Consistent with our previous report (Herman et al., 2013), gabazine (100 $\mu \mathrm{M})$ produced a significant reduction in holding current in both RS and LTB CRF1+ neurons from AIR mice $(17.0 \pm 2.9 \mathrm{pA}$ and $14.2 \pm 2.1 \mathrm{pA}$, respectively; $p<0.05$ by one-sample $t$ test; RS, $n=5$; LTB, $n=8$; Fig. $3 A$, top trace, $C$ ). In contrast, immediately following chronic ethanol exposure gabazine did not significantly alter the holding current in either RS or LTB neurons $(1.1 \pm 1.0 \mathrm{pA}$ and $2.3 \pm 0.9$ pA, respectively; RS, $n=4$; LTB, $n=7$; Fig. $3 A$, middle trace, $C$ ), and this loss of effect persisted in neurons from CIE-WD mice $(4.6 \pm 0.3 \mathrm{pA}$ and $3.1 \pm 1.3 \mathrm{pA}$, respectively; RS, $n=2$; LTB, $n=$ 13; Fig. $3 A$, bottom trace, $C$ ). Two-way ANOVA revealed a significant effect of treatment $\left(F_{(2,34)}=23.0, p<0.001 ;\right.$ Fig. $\left.3 C\right)$, but not of cell type $\left(F_{(1,34)}=0.04, p>0.05\right)$, and no significant interaction $\left(F_{(2,34)}=0.2, p>0.05\right)$. Gabazine produced no change in holding current in either RS or LS CRF1- neurons from AIR mice ( $1.2 \pm 0.4 \mathrm{pA}$ and $1.1 \pm 1.1 \mathrm{pA}$, respectively; RS, $n=4$; LS, $n=8$; Fig. $3 B$, top trace, $D)$. However, in CRF1neurons from CIE mice, gabazine produced a significant reduction in holding current in LS neurons $(11.1 \pm 1.3 \mathrm{pA} ; p<0.05$; $n=6$; Fig. $3 B$, middle trace, $D$ ) that was not observed in RS neurons $(2.3 \pm 1.2 \mathrm{pA} ; n=6$; Fig. $3 D)$. The significant reduction in holding current produced by gabazine was also observed in LS CRF1 - neurons from CIE-WD mice $(14.5 \pm 2.7 \mathrm{pA} ; p<0.05$; $n=10$; Fig. $3 B$, bottom trace, $D$ ), but not in RS CRF1 - neurons from CIE-WD mice ( $1.6 \pm 0.6 \mathrm{pA} ; n=8$; Fig. $3 D)$. Two-way ANOVA revealed a significant effect of treatment $\left(F_{(2,36)}=7.05\right.$, $p<0.01$; Fig. $3 D)$ and of cell type $\left(F_{(1,36)}=21.82, p<0.001\right)$, as well as a significant interaction $\left(F_{(2,36)}=6.05, p<0.01\right)$. Based on our previous report showing connectivity between CeA CRF1 - and CRF1+ neurons (Herman et al., 2013), these results suggest that chronic ethanol exposure produces an increase in phasic and tonic inhibition specifically in LS CRF1 - neurons and a subsequent loss of tonic inhibition in CRF1+ neurons in the CeA.

\section{The relative sensitivity of $\delta$ subunit-containing $\mathrm{GABA}_{\mathrm{A}}$ receptors in CRF1 + and CRF1 - neurons is unchanged by CIE and CIE-WD}

Based on our previous work demonstrating a tonic conductance that could be stimulated in CRF1- neurons (Herman et al., 2013), we hypothesized that the tonic conductance observed in late-spiking $\mathrm{CRF} 1-$ was mediated by $\delta$ subunit-containing $\mathrm{GABA}_{\mathrm{A}}$ receptors. To investigate the underlying mechanisms behind the changes in tonic conductance observed in CRF1+ and CRF1 - neurons in the CeA, we performed whole-cell voltageclamp recordings of neurons from AIR, CIE and CIE-WD mice using the $\delta$ subunit-preferring agonist gaboxadol (THIP) to assess the relative sensitivity of $\delta$ subunit-containing $\mathrm{GABA}_{\mathrm{A}}$ receptors. THIP $(5 \mu \mathrm{M})$ increased the holding current in all CRF1neurons examined; however, in CRF1 - neurons from AIR mice, LS CRF1- neurons displayed a significantly greater increase as compared to RS CRF1 - neurons $(75.9 \pm 7.8 \mathrm{pA}$ and $20.9 \pm 7.3$ pA, respectively; LS, $n=8$; RS, $n=5$; Fig. $4 A, C)$. The greater increase in holding current in LS CRF1- neurons compared to RS neurons was also observed in neurons from CIE mice (52.4 \pm $9.5 \mathrm{pA}$ and $20.1 \pm 5.8 \mathrm{pA}$, respectively; $\mathrm{LS}, n=6$; RS, $n=6$; Fig. $4 B, C)$ and in neurons from CIE-WD mice (58.3 $\pm 10.4 \mathrm{pA}$ and $23.8 \pm 3.6$ pA, respectively; LS, $n=9$; RS, $n=7$; Fig. $4 C$ ). Two-way ANOVA revealed a significant effect of cell type $\left(F_{(1,35)}=34.2, p<0.001\right.$; Fig. $\left.4 C\right)$, but not of treatment $\left(F_{(2,35)}=\right.$ $0.8, p>0.05)$, and no significant interaction $\left(F_{(2,35)}=0.9, p>\right.$ $0.05)$. THIP produced a small and variable increase in holding current in both RS and LTB CRF1+ neurons, and there was no significant effect of treatment $\left(F_{(2,22)}=0.2, p>0.05\right)$ or cell type $\left(F_{(1,22)}=0.06, p>0.05\right)$, and no significant interaction $\left(F_{(2,22)}=\right.$ $0.5, p>0.05)$ in CRF1+ neurons from AIR, CIE, or CIE-WD mice (Fig. $4 D$ ). These data suggest that LS CRF1- neurons possess a greater number and/or sensitivity of $\delta$ subunit-containing $\mathrm{GABA}_{\mathrm{A}}$ receptors, which may be the source of the tonic conductance observed in CRF1 - neurons from CIE and CIE-WD mice.

\section{The relative sensitivity of CRF1 + and CRF1 - neurons to acute ethanol is unchanged by CIE or CIE-WD}

Based on the differential sensitivity of CRF1+ and CRF1- neurons to THIP and the role of the $\delta$ subunit in the effects of ethanol, we hypothesized that CRF1+ and CRF1- neurons would have a similar relative sensitivity to acute ethanol as what was observed with THIP. To further examine the mechanisms underlying the changes in tonic conductance in CRF1+ and CRF1neurons following CIE and CIE-WD, we assessed the relative sensitivity of these cells to acute ethanol exposure. Ethanol (44 $\mathrm{mM}$ ) increased the holding current in all CRF1- neurons from AIR mice, but the increase was significantly greater in LS neurons compared to RS neurons $(11.8 \pm 2.1 \mathrm{pA}$ and $3.6 \pm 1.4 \mathrm{pA}$, respectively; LS, $n=7$; RS, $n=5$; Fig. $5 A, C$ ). The greater increase in holding current in LS CRF1 - neurons compared to RS neurons was also observed in neurons from CIE mice $(14.4 \pm 2.4 \mathrm{pA}$ and $7.2 \pm 1.3$ pA, respectively; LS, $n=5$; RS, $n=6$; Fig. $5 B, C)$ and in neurons from CIE-WD mice $(9.9 \pm 1.7 \mathrm{pA}$ and $2.7 \pm 0.8$ pA, respectively; LS, $n=8$; RS, $n=4$; Fig. $5 C$ ). Two-way ANOVA 
A

\section{CRF1+ Low Threshold Bursting}

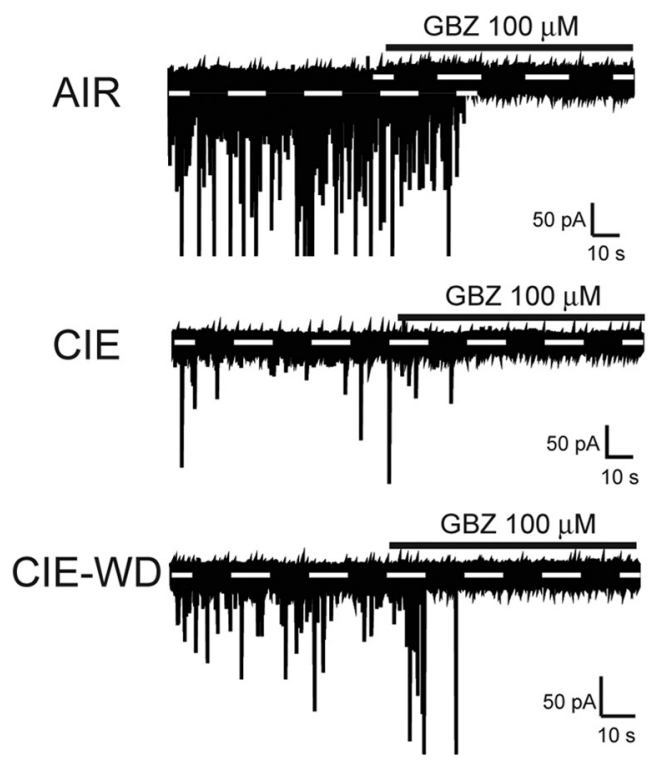

C

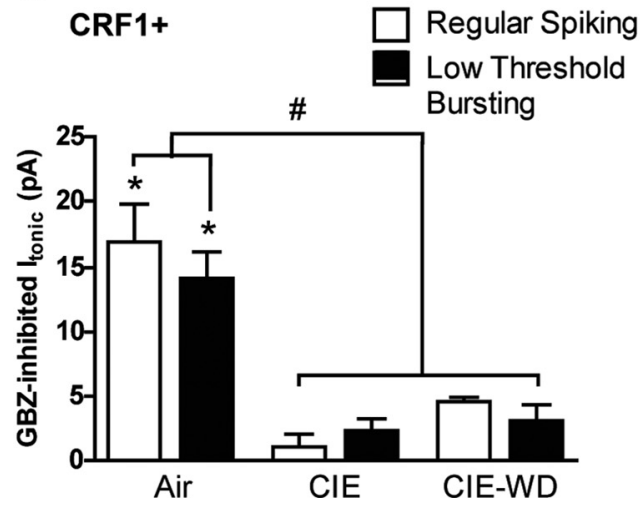

B

\section{CRF1- Late Spiking}

AIR

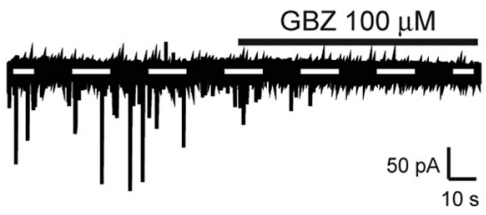

GBZ $100 \mu \mathrm{M}$
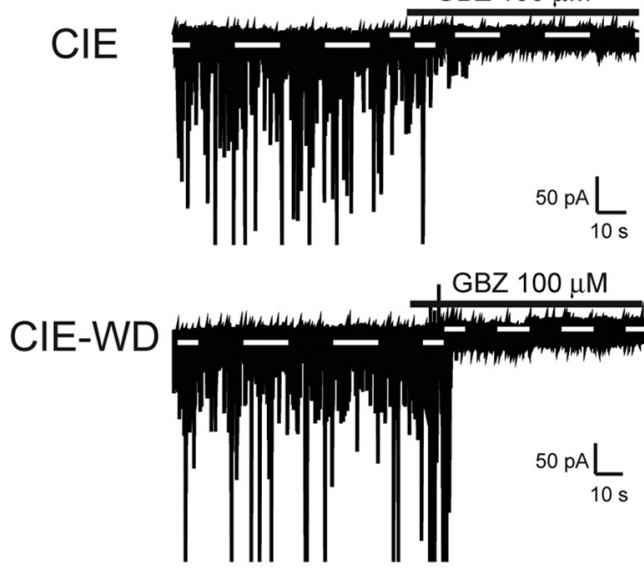

D CRF1-

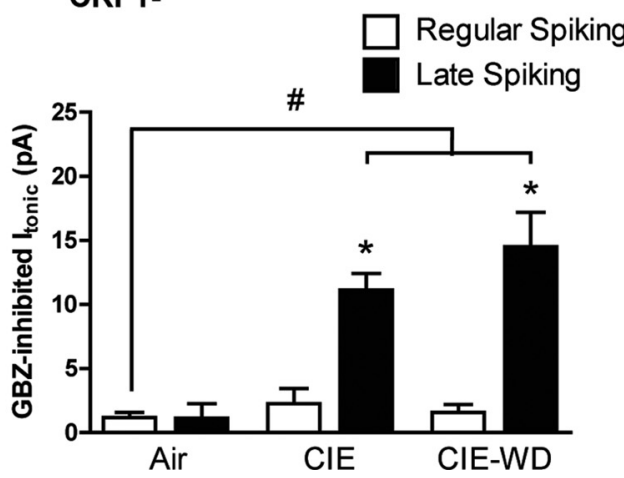

Figure 3. A, Representative voltage-clamp recordings from CRF1 + neurons from an AIR mouse (top), a CIE mouse (middle), and a CIE-WD mouse (bottom) during superfusion of GBZ (100 $\mu \mathrm{M}$ ). $B$, Representative voltage-clamp recordings from late-spiking CRF1 - neurons from an AIR mouse (top), a CIE mouse (middle), and a CIE-WD mouse (bottom) during superfusion of GBZ (100 $\mu \mathrm{M}$ ). C, Summary of the tonic current in CRF1+ neurons revealed by superfusion of GBZ in regular-spiking (AIR, $n=5 ;(\mathrm{IE}, n=4 ; \mathrm{CIE}-\mathrm{WD}, n=2)$ and low-threshold bursting neurons (AIR, $n=8$; (IE, $n=7$; CIE-WD, $n=13) .{ }^{*} p<0.05$ by one sample t-test; ${ }^{*} p<0.001$ by treatment. $D$, Summary of the tonic current in CRF1 - neurons revealed by superfusion of GBZ in regular-spiking $(n=4$ AIR, $n=6$ CIE and $n=8$ CIE-WD) and late-spiking neurons (AIR, $n=8$; CIE, $n=6$; (IE-WD, $n=10$ ). ${ }^{*} p<0.01$ by treatment; ${ }^{*} p<0.001$ by cell type.

revealed a significant effect of cell type $\left(F_{(1,29)}=24.6, p<0.0001\right.$; Fig. $5 C)$, but not of treatment $\left(F_{(2,29)}=3.0, p>0.05\right)$, and no significant interaction $\left(F_{(2,29)}=0.05, p>0.05\right)$. There was no difference in the sensitivity of sIPSC frequency to acute ethanol between RS and LS CRF1- neurons and no effect of CIE or CIE-WD (Fig. 5D). There was no significant effect of ethanol on sIPSC amplitude in RS or LS CRF1 - neurons from AIR, CIE, or CIE-WD mice, either by cell type $\left(F_{(1,26)}=0.09, p>0.05\right)$ or treatment $\left(F_{(2,26)}=0.9, p>0.05\right)$, and no significant interaction $\left(F_{(2,26)}=0.5, p>0.05\right)$. Acute ethanol produced small and variable effects on holding current in both RS and LTB CRF1+ neurons, and there was no significant effect of treatment $\left(F_{(2,22)}=\right.$ $0.2, p>0.05)$ or cell type $\left(F_{(1,22)}=0.06, p>0.05\right)$ and no significant interaction $\left(F_{(2,22)}=0.5, p>0.05\right)$ in CRF1+ neurons from AIR, CIE, or CIE-WD mice (Fig. 5E). There was also no difference in the effect of ethanol on sIPSC frequency in RS and
LTB CRF1+ neurons between AIR, CIE, and CIE-WD mice (Fig. $5 F)$. There was also no significant effect of ethanol on sIPSC amplitude in RS or LTB CRF1+ neurons from AIR, CIE, or CIE-WD mice, either by cell type $\left(F_{(1,17)}=0.6, p>0.05\right)$ or by treatment $\left(F_{(2,17)}=0.3, p>0.05\right)$, and no significant interaction $\left(_{(2,17)}=2.3, p>0.05\right)$.

Tonic inhibitory transmission is selectively altered in CeA projection neurons

As we reported previously that CRF1 + neurons make up a subset of neurons that project out of the CeA in to the dlBNST (Herman et al., 2013), we predicted that this subset of CRF1+ neurons would also exhibit a reduced tonic conductance following CIE. To test this hypothesis, we performed whole-cell voltage-clamp recordings in CRF1+ and CRF1 - neurons retrogradely labeled with fluorescent microspheres injected into the dIBNST of mice 
A

Regular Spiking

AIR

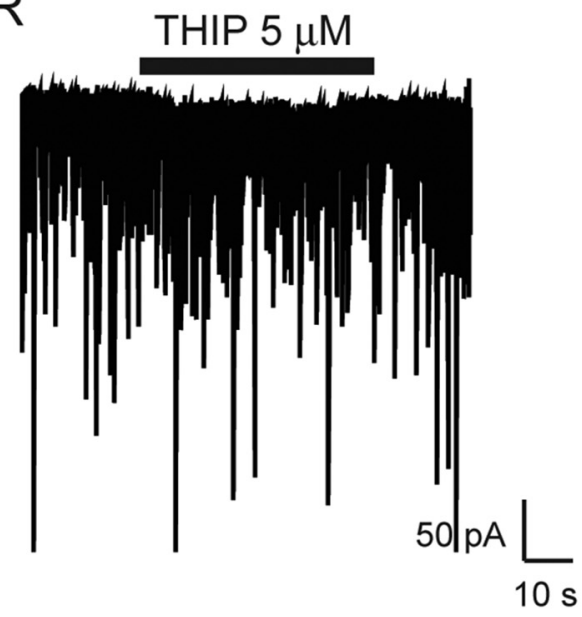

B

Regular Spiking

CIE

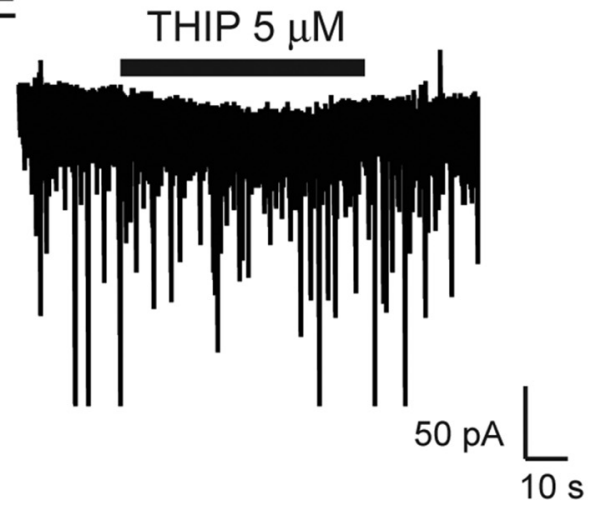

Late Spiking

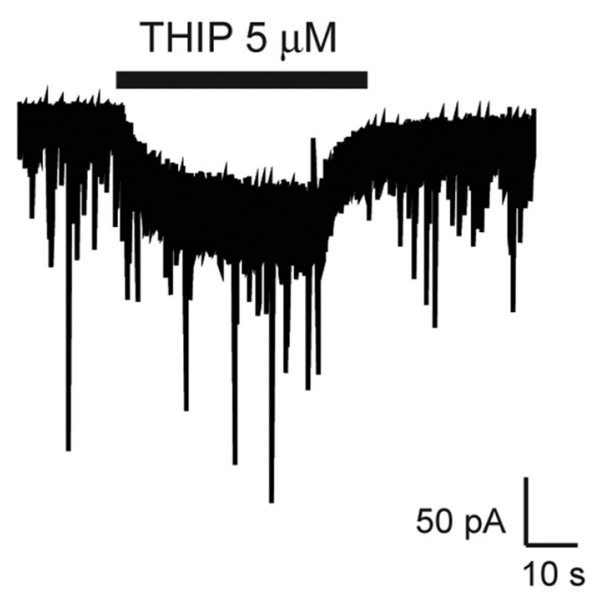

Late Spiking

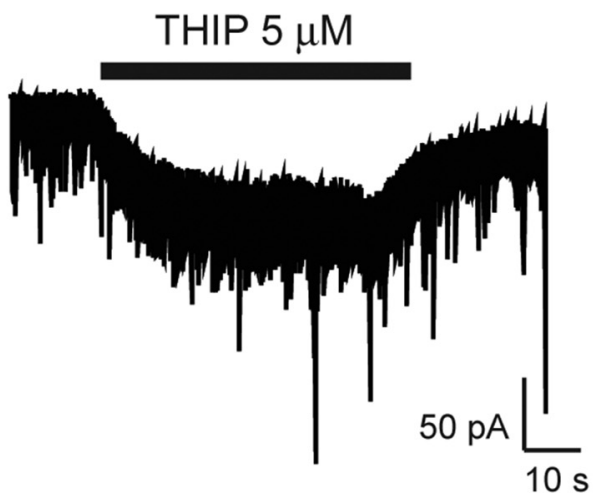

C

CRF1-

D

CRF1+ Regular Spiking Late Spiking

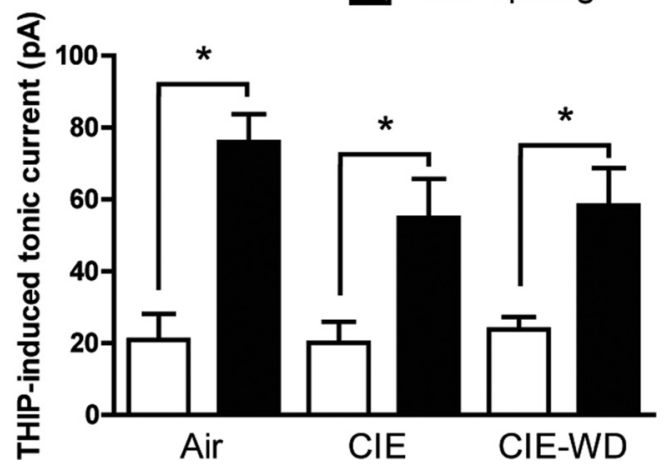

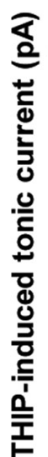

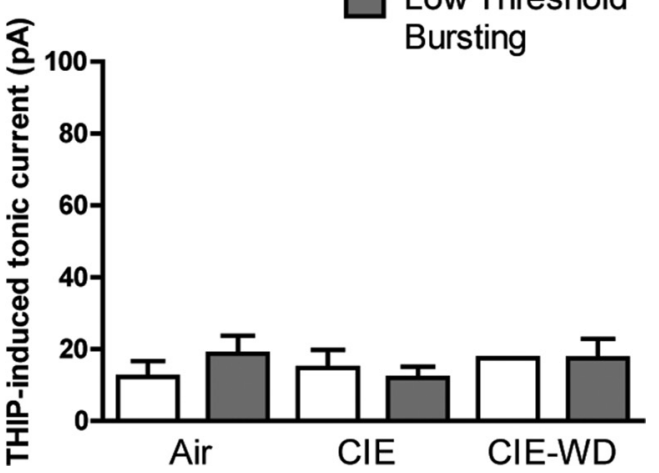

Figure 4. A, Representative voltage-clamp recordings from a regular-spiking (left) and a late-spiking (right) CRF1 - neuron from an AIR mouse during superfusion of THIP (5 $\mu$ M). $\boldsymbol{B}$, Representative voltage-clamp recordings from a regular-spiking (left) and a late-spiking (right) CRF1 - neuron from a CIE mouse during superfusion of THIP (5 $\mu \mathrm{M})$. C, Summary of the tonic current induced by THIP in regular-spiking (AIR, $n=5 ;$ CIE, $n=6$; CIE-WD, $n=7$ ) and late-spiking neurons (AIR, $n=8 ;$ CIE, $n=6 ;$ CIE-WD, $n=9)$. ${ }^{*} p<0.001$ by cell type. $\boldsymbol{D}$, Summary of the tonic current induced by THIP in regular-spiking (AIR, $n=5$; CIE, $n=5$; CIE-WD, $n=1)$ and low threshold bursting neurons (AIR, $n=6$; CIE, $n=6$; CIE-WD, $n=5)$. 
subsequently exposed to AIR, CIE, or CIE-WD. Projection neurons were identified using IR-DIC optics during recording (Fig. 6A, left) and by the presence of red fluorescent microspheres in the cell body (Fig. 6A, right). CRF1+ projection neurons were identified using IR-DIC optics (Fig. 6B, left), by GFP expression (middle), and by red microspheres detected in the cell body (right). CRF1 - neurons were exclusively of the RS cell type, and the majority ( 24 of $30,80 \%$ ) of CRF1+ projection neurons were of the LTB cell type. Gabazine $(100 \mu \mathrm{M})$ produced a significant reduction in holding current in all CRF1+ projection neurons from AIR mice $(11.5 \pm 2.1 \mathrm{pA} ; n=11$; Fig. $6 C$, top trace, $D)$. In contrast, in CRF1+ projection neurons from CIE mice, gabazine produced no change in the holding current $(0.6 \pm 1.7 \mathrm{pA} ; p<0.05$ compared to AIR; $n=8$; Fig. $6 C$, middle trace, $D$ ), and the same loss of effect was observed in CRF1+ projection neurons from CIE-WD mice $(1.5 \pm 1.4 \mathrm{pA} ; p<0.05$ compared to AIR; $n=8$; Fig. $6 C$, bottom trace, $D)$. Similar to what was observed in CRF1+ projection neurons, in CRF1projection neurons from AIR mice, gabazine produced a significant reduction in holding current $(14.5 \pm 3.5 \mathrm{pA} ; n=8$; Fig. $6 E)$ that was not observed in CRF1 - projection neurons from CIE mice $(-0.4 \pm$ $0.9 \mathrm{pA} ; p<0.05$ compared to AIR; $n=7$; Fig. $6 E)$ or CIE-WD mice $(1.7 \pm 2.0 \mathrm{pA}$; $n=6 ; p<0.05$ compared to AIR; Fig. $6 E$ ). The presence of a significant tonic conductance in projecting CRF1- neurons from AIR mice is surprising given the absence of tonic conductance observed in unlabeled CRF1 - neurons (Fig. 3D). Although it is possible that microspheres independently alter tonic GABA signaling in neurons in which they are taken up, it is more likely that projection neurons were not included in the neurons examined in the previous groups, as projection neurons make up only a small proportion of CeA CRF1 - neurons. These data suggest that all projection neurons (CRF1+ and CRF1-) are under a significant amount of tonic inhibitory control that is lost following chronic ethanol exposure, and that this loss persists into withdrawal.

CRF1 + CeA projection neurons display an increased excitability and loss of sensitivity to acute ethanol following CIE

We predicted that the loss of tonic inhibitory control of CRF1+ CeA projection neurons would impact the excitability of these cells. To test this hypothesis, we per-
A
Regular Spiking

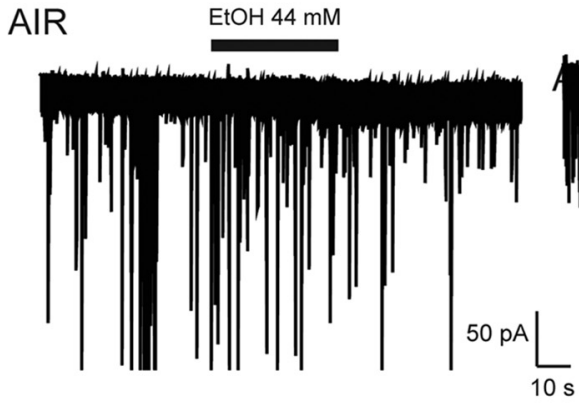

B

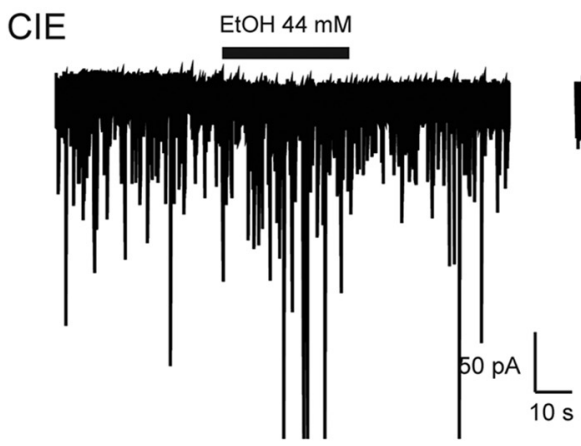

Regular Spiking

C

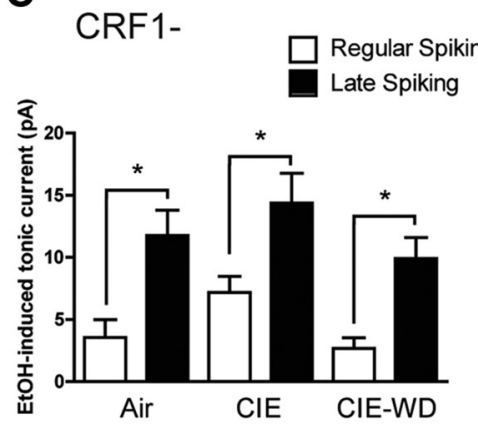

E

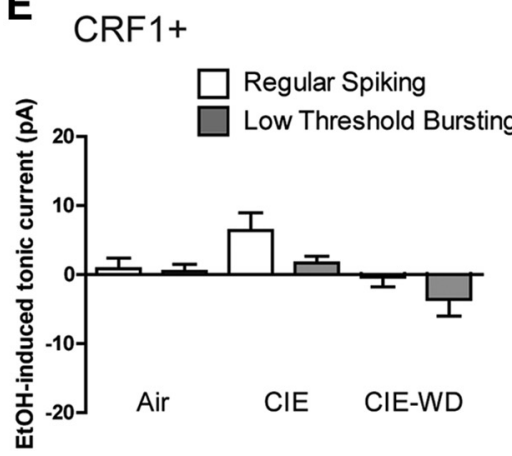

Late Spiking

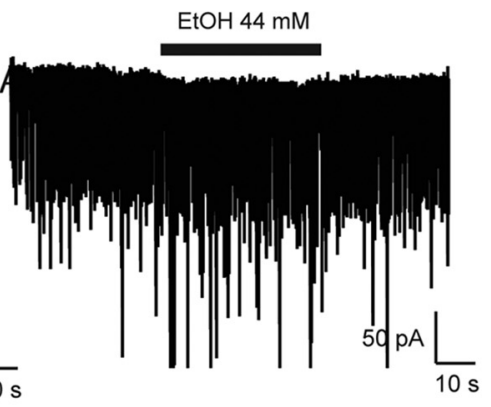

Late Spiking

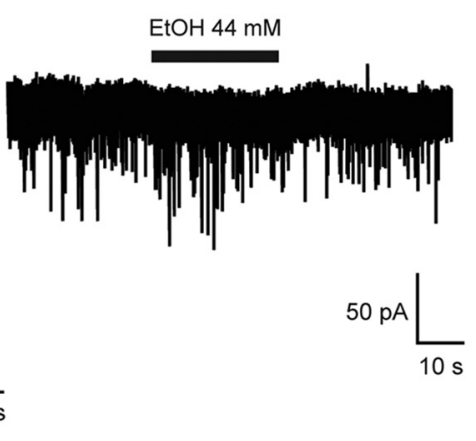

D

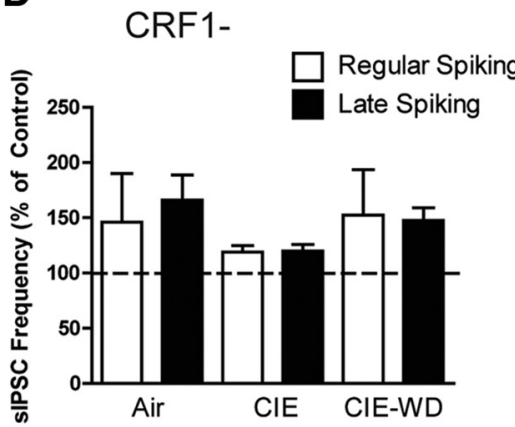

$\mathbf{F}$
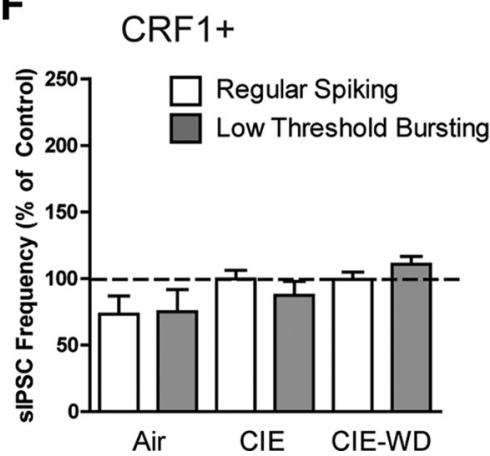

Figure 5. A, Representative voltage-clamp recordings from a regular-spiking (left) and a late-spiking (right) CRF1 - neuron from an AIR mouse during superfusion of EtOH ( $44 \mathrm{mM}$ ). $\boldsymbol{B}$, Representative voltage-clamp recordings from a regular-spiking (left) and a late-spiking (right) CRF1 - neuron from a CIE mouse during superfusion of ethanol (44 mM). C, Summary of the tonic current induced by Et0H in regular-spiking (AIR, $n=5 ; \mathrm{CIE}, n=6$; CIE-WD, $n=4$ ) and late-spiking CRF1- neurons (AIR, $n=7 ; \mathrm{CIE}, n=$ 5 ; CIE-WD, $n=8) .{ }^{*} p<0.0001$ by cell type. $D$, Summary of the change in sIPSC frequency induced by EtOH in regular-spiking (AIR, $n=5 ; \mathrm{CIE}, n=6$; (IE-WD, $n=4$ ) and late-spiking (RF1- neurons (AIR, $n=7 ; \mathrm{CIE}, n=5$; (IE-WD, $n=8$ ). E, Summary of the tonic current induced by EtOH in regular-spiking (AIR, $n=10 ; \mathrm{CIE}, n=4$; CIE-WD, $n=5)$ and LTB CRF1 + neurons (AIR, $n=9$; $\mathrm{CIE}, n=5$; CIE-WD, $n=7)$. F, Summary of the change in sIPSC frequency induced by EtOH in regular-spiking (AIR, $n=4$; $\mathrm{CIE}, n=$ 4 ; CIE-WD, $n=3$ ) and LTB CRF1+ neurons (AIR, $n=4$; CIE, $n=4$; (IE-WD, $n=4)$. 


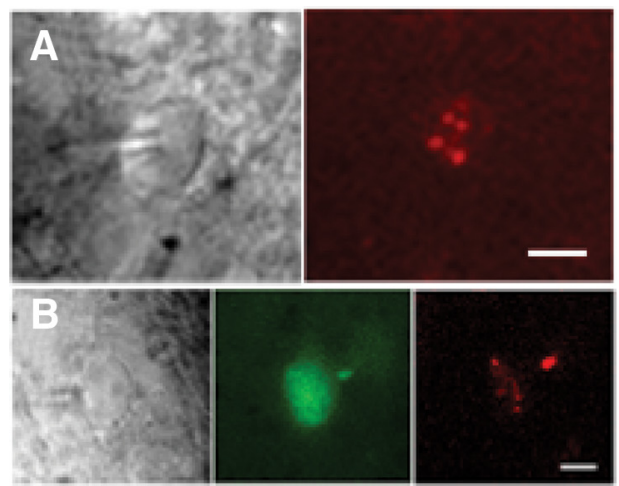

C CRF1+ Low Threshold Bursting
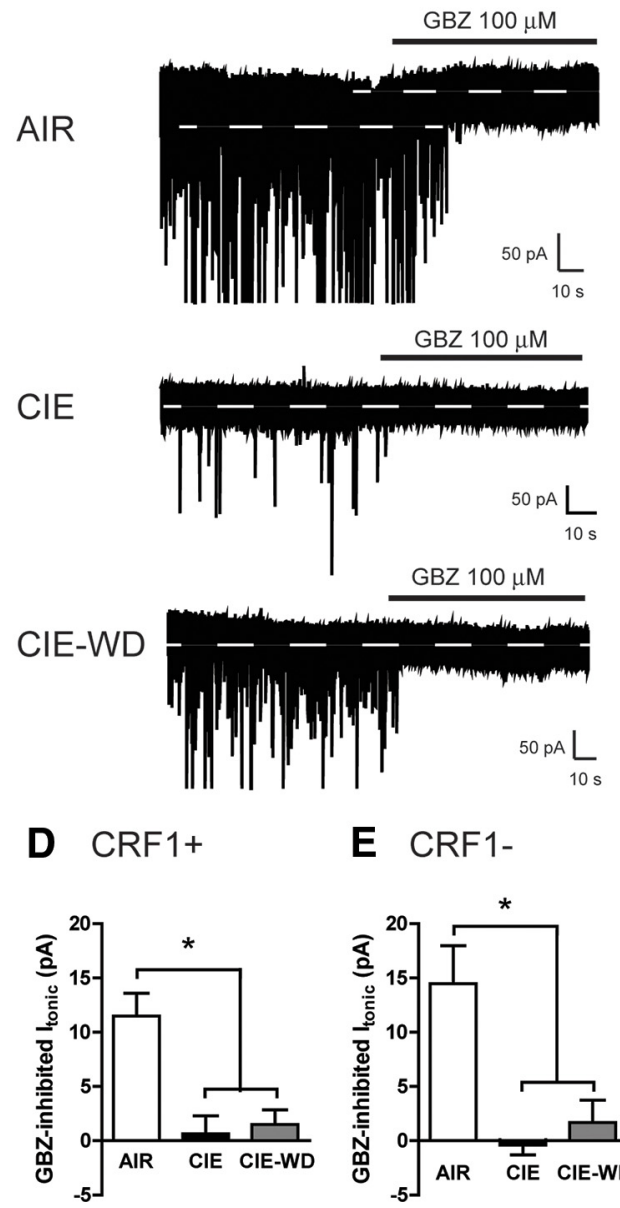

E CRF1-

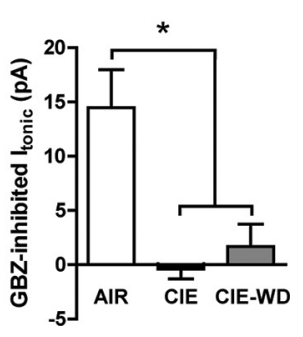

Figure 6. A, A $60 \times$ magnification of a CRF1 - CeA neuron in IR-DIC optics (left) and red fluorescent optics depicting retrogradely transported microspheres (right) indicating a projection to the dIBNST. B, A60 × magnification of a CRF1 + CeA neuron in IR-DIC optics (left), green fluorescent optics (middle), and red fluorescent optics depicting retrogradely transported microspheres (right). C, Representative voltage-clamp recordings from CRF1+ projection neurons from an AIR mouse (top), a CIE mouse (middle), and a CIE-WD mouse (bottom) during superfusion of GBZ $(100 \mu \mathrm{M})$. D, Summary of the tonic current revealed by gabazine in CRF1+ projection neurons from $\operatorname{AIR}(n=11), \mathrm{CIE}(n=8)$, and CIE-WD $(n=8)$ mice. $\boldsymbol{E}$, Summary of the tonic current revealed by gabazine in CRF1 - projection neurons from $\operatorname{AIR}(n=8), \operatorname{CIE}(n=7)$, and CIE-WD $(n=6)$ mice. ${ }^{*} p<0.05$ by one-way ANOVA. Scale bars: $20 \mu \mathrm{m}$.

formed extracellular cell-attached recordings in microspherelabeled CRF1+ neurons from AIR and CIE mice. CRF1+ projection neurons from AIR mice displayed a baseline firing rate of $2.9 \pm 0.6 \mathrm{~Hz}(n=8$; Fig. $7 A$, left, $B)$. CRF1+ projection neurons from CIE mice displayed a baseline firing rate that was significantly higher than that observed in neurons from AIR mice $(8.2 \pm 2.5 \mathrm{~Hz} ; p<0.05$ compared to AIR; $n=5$; Fig. $7 A$, right, $B)$. To determine how the changes in baseline excitability of CRF1+ CeA projection neurons would impact the effects of acute ethanol on firing discharge, we performed cell-attached recordings during superfusion of acute ethanol in CRF1+ projection neurons from AIR and CIE mice. In AIR mice, ethanol (44 mM) significantly increased the firing rate of $\mathrm{CRF} 1+$ projection neurons from $2.9 \pm 0.6 \mathrm{~Hz}$ to $4.7 \pm 0.6 \mathrm{~Hz}(p<0.05 ; n=8$; Fig. $7 C$, left, $D)$. In contrast, in CRF1+ projection neurons from CIE mice, ethanol did not significantly alter the firing rate $(8.2 \pm 2.5 \mathrm{~Hz}$ compared to $7.1 \pm 1.9 \mathrm{~Hz} ; n=5$; Fig. $7 C$, right, $D$ ). When the firing rate of each cell was normalized to baseline firing levels, acute ethanol increased the firing rate of CRF1+ projection neurons to $180.1 \pm 21.2 \%$ of control $(p<0.05 ; n=8)$ in AIR mice, and this increase was completely lost in CRF1+ projection neurons from CIE mice ( $96.4 \pm 12.5 \%$ of control; $p<0.05$ compared to AIR; $n=5$; Fig. $7 E$ ). Together, these data indicate that CRF1+ projection neurons have an increased level of baseline activity after chronic ethanol exposure and can no longer increase their firing rate with acute ethanol exposure. These changes in baseline excitability and sensitivity to acute ethanol likely have significant consequences in the extended amygdala circuitry.

\section{Discussion}

This study provides new insight into the functional changes in inhibitory signaling in the CeA CRF1 circuitry following chronic ethanol exposure. Collectively, the data demonstrate that chronic ethanol exposure produces significant decreases in the phasic and tonic inhibition of CRF1 + neurons, regardless of the specific cell type. The loss of tonic inhibition in CRF1+ neurons occurs in parallel with an increase in phasic and tonic signaling in the subpopulation of LS CRF1 - neurons. LS CRF1 - neurons display an increased sensitivity to the $\delta$ subunit-preferring agonist THIP and to acute ethanol as compared to regular-spiking CRF1 - neurons, suggesting that the increased tonic signaling is mediated by $\delta$ subunit-containing $\mathrm{GABA}_{\mathrm{A}}$ receptors that are present, but not active in the naive state. The loss of tonic inhibition was also seen in CRF1 + neurons that project into the dlBNST, along with an increase in baseline firing and loss of sensitivity to acute ethanol. Together, these data suggest that chronic ethanol exposure produces a functional switch in tonic signaling in the CeA such that the balance of inhibitory control shifts from CRF1+ projection neurons to LS CRF1 - interneurons. This switch results in increased output of the CeA CRF1 system via disinhibition of projection neurons and includes a loss of sensitivity to acute ethanol. Interestingly, many of these changes persist into withdrawal, suggesting that they represent long-term neuroadaptations that could potentially play a role in alcohol dependence behaviors like escalated alcohol intake and the susceptibility to relapse. A schematic of the proposed inhibitory circuitry regulating activity of the CRF1 system in naive mice and the changes in inhibitory signaling that emerge after chronic ethanol exposure is shown in Figure 8.

As the CeA is primarily a GABAergic nucleus (Pitkänen and Amaral, 1994), inhibitory signaling is the predominant neurotransmission, the magnitude and type of which is determined presynaptically by GABA release and postsynaptically by the type and expression pattern of $\mathrm{GABA}$ receptor. $\mathrm{GABA}_{\mathrm{A}}$ receptor inhibition takes two main forms: phasic and tonic. Phasic inhibition mediates fast, point-to-point transmission with a relatively short time scale and rapid deactivation/desensitization. In contrast, tonic inhibition is characterized by a persistent inhibitory tone 
that dampens excitability (for review, see Glykys and Mody, 2007a; Belelli et al., 2009). Distinct receptor populations with specific $\mathrm{GABA}_{\mathrm{A}}$ receptor subunit configurations mediate the different types of inhibition and the relative properties of each (Semyanov et al., 2004). We showed previously that the tonic signaling in CRF1+ neurons is driven by action potentialdependent GABA release and is mediated by $\mathrm{GABA}_{\mathrm{A}}$ receptors containing the $\alpha 1$ subunit (Herman et al., 2013). The loss of tonic signaling in CRF1+ neurons after chronic ethanol could be the result of several (possibly converging) mechanisms. One possibility is that a decrease in presynaptic GABA release removes the input required to stimulate these receptors. This idea is consistent with the decrease in sIPSC frequency in CRF1+ neurons after chronic ethanol. Another possibility is that the $\mathrm{GABA}_{\mathrm{A}}$ receptors located on $\mathrm{CRF} 1+$ neurons are downregulated so that there are fewer receptors to carry a tonic conductance. This interpretation is consistent with an overall downregulation of $\mathrm{GABA}_{\mathrm{A}}$ receptors as suggested by the decrease in sIPSC amplitude that we observed in CRF1+ neurons after chronic ethanol exposure. However, the decrease in sIPSC amplitude was only observed in LTB CRF1+ neurons, but the loss of tonic conductance was observed in both LTB and RS neurons, suggesting that an overall downregulation of $\mathrm{GABA}_{\mathrm{A}}$ receptors is not the dominant mechanism behind the loss of tonic inhibition. A third possibility is that the subunit composition and/or or synaptic localization of $\mathrm{GABA}_{\mathrm{A}}$ receptor subunits is altered in CRF1+ neurons after chronic ethanol, similar to what has been observed in the hippocampus (Liang et al., 2009) and thalamus (Werner et al., 2016) following chronic ethanol treatment. Changes in sIPSC kinetics (rise and decay times) in CRF1+ neurons following chronic ethanol supports the idea that the composition of $\mathrm{GABA}_{\mathrm{A}}$ receptor subunits is altered in CRF1+ neurons following chronic ethanol. However, while the decrease in sIPSC frequency partially recovered but the loss of tonic conductance persisted into withdrawal, the changes in sIPSC amplitude and decay were restored to control levels in withdrawal, suggesting that they may represent independent neuroadaptations. In addition, changes in sIPSC kinetics were also observed in CRF1- neurons, suggesting that these changes occur independent of changes in tonic conductance.

In contrast to the potential changes in $\mathrm{GABA}_{\mathrm{A}}$ receptor expression and/or local-
A CRF1+

B
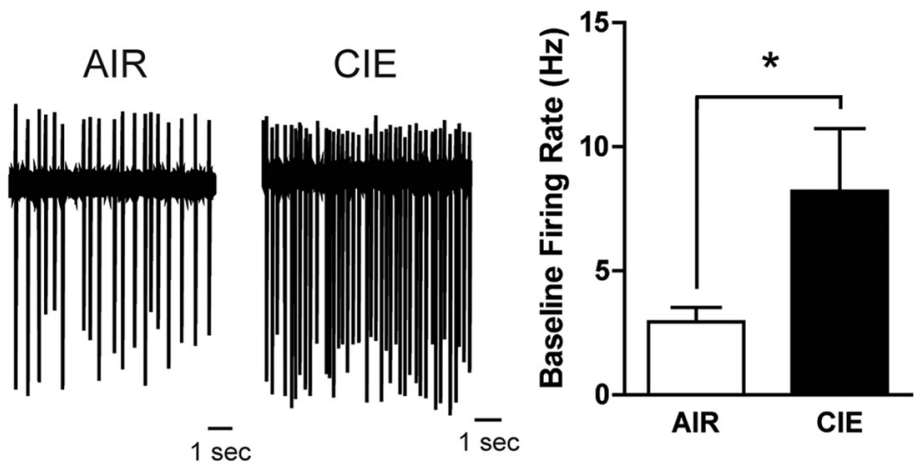

C $\mathrm{CRF} 1+$

Control

AIR

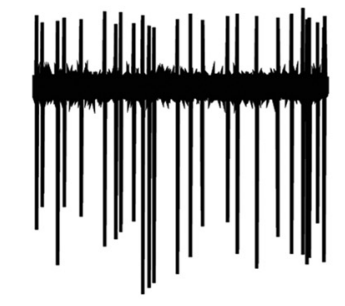

CIE

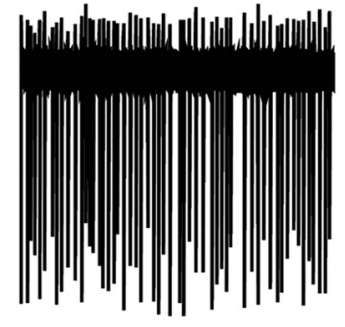

EtOH $44 \mathrm{mM}$

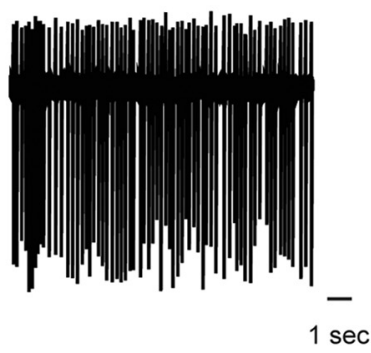

EtOH $44 \mathrm{mM}$

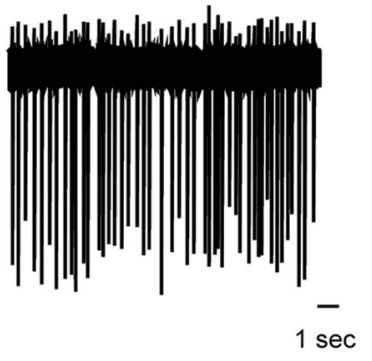

$\mathbf{E}$
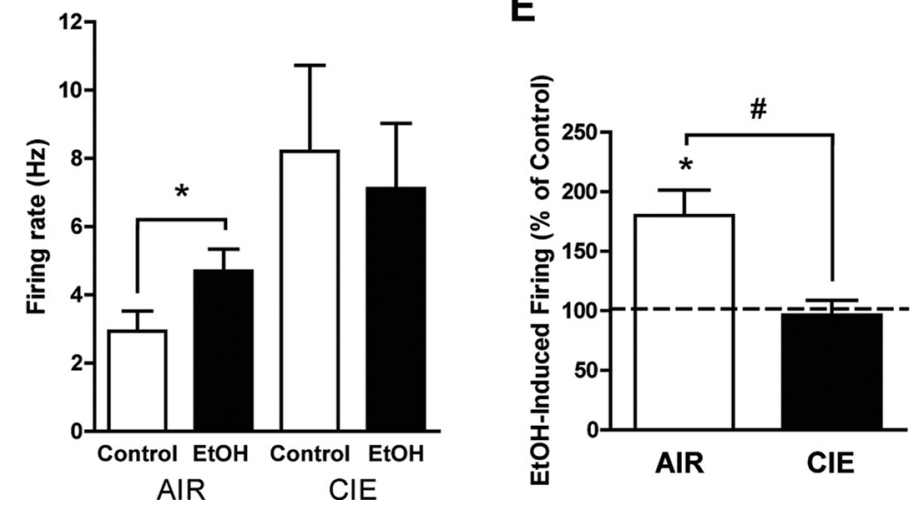

Figure 7. $A$, Representative cell-attached recordings from CRF1 + neurons containing microspheres from an AIR mouse (left trace) and from a (IE mouse (right trace). $\boldsymbol{B}$, Summary of the average baseline firing rate in CRF1+ neurons from AIR mice $(n=8)$ and CRF1+ neurons from CIE mice $(n=5) .{ }^{*} p<0.05$ by unpaired $t$ test. $C$, Representative cell-attached recordings from CRF1+ neurons containing microspheres from an AIR mouse (left traces) and from a CIE mouse (right traces) before (upper traces) and during (lower traces) superfusion of EtOH (44 $\mathrm{mm}$ ). $\boldsymbol{D}$, Summary of the average firing rate before and during EtOH superfusion in CRF1+ neurons from AIR mice $(n=8)$ and CRF1+ neurons from CIE mice $(n=5)$. ${ }^{*} p<0.05$ by paired $t$ test. $\boldsymbol{E}$, Summary of the average change in firing rate (percentage of control) following EtOH superfusion in CRF1+ neurons from AIR mice $(n=8)$ and CRF1+ neurons from CIE mice $(n=5) .{ }^{*} p<0.05$ by one-sample $t$ test; ${ }^{\#} p<0.05$ by unpaired $t$ test. 


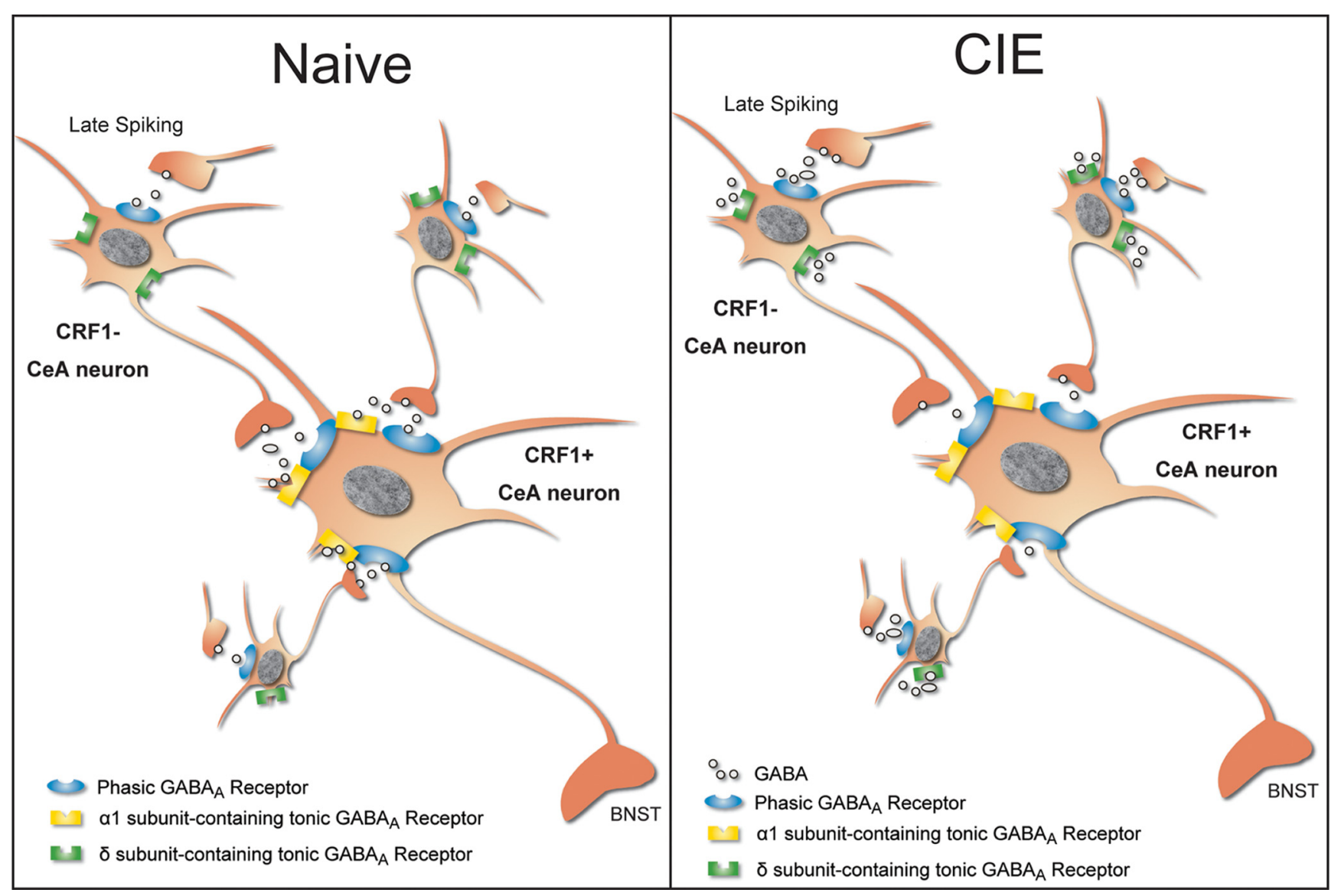

Figure 8. Proposed schematic of the changes in inhibitory signaling in CRF1 + and CRF1 - neurons that make up the CeA microcircuitry. In the CeA of naive mice (left) the majority of inhibitory signaling (phasic and tonic) is on (RF1 + neurons, some of which project out of the CeA into the BNST. CRF1 - neurons possess the potential for enhanced tonic signaling that can be stimulated by specific $\mathrm{AABA}_{A}$ receptor agonists or by acute ethanol. After (IE vapor exposure (right), there is a switch in inhibitory control such that the dominant inhibitory drive (phasic and tonic) is on late-spiking CRF1 - neurons. The enhanced inhibition on this select population of CRF1 - neurons results in a reduction in phasic inhibition in CRF1 + neurons and a subsequent loss of the tonic inhibition that was driven by phasic GABA release onto CRF1 + neurons. The net result of this functional switch in inhibitory control is an increase in the baseline activity of CRF1+ neurons that project out of the CeA into the BNST via disinhibition and the loss of sensitivity of these neurons to the effects of acute ethanol on firing.

ization in CRF1+ neurons following chronic ethanol, our data suggest that the tonic conductance observed in LS CRF1- neurons following $\mathrm{CIE}$ is mediated by $\mathrm{GABA}_{\mathrm{A}}$ receptors that are present in control conditions. The relative sensitivity of LS $\mathrm{CRF} 1$ - neurons to the $\mathrm{GABA}_{\mathrm{A}}$ receptor agonist THIP and to acute ethanol and the lack of effect of chronic ethanol treatment on that relative sensitivity suggest that although $\delta$ subunitcontaining receptors are present on LS CRF1- neurons in the basal state, they are not occupied. As these receptors are located at extrasynaptic sites (Glykys and Mody, 2007a), they are likely not activated unless ambient GABA levels reach a sufficient threshold, which may not occur in the naive CeA. We have previously reported a rise in ambient GABA levels after chronic ethanol administration (Roberto et al., 2004), which is consistent with the potential for activation of extrasynaptic $\mathrm{GABA}_{\mathrm{A}}$ receptors containing the $\delta$ subunit and the significant increase in tonic signaling that we observed in LS CRF1 - neurons. Interestingly, despite the increase in activity of $\delta$ subunit-containing $\mathrm{GABA}_{\mathrm{A}}$ receptors in LS CRF1- neurons following chronic ethanol administration, acute ethanol was still able to stimulate a further increase in tonic signaling, suggesting that the occupation/activation is submaximal.

The CRF system, and particularly CRF1, in the CeA have been implicated in the effects of stress, anxiety, and all stages of alcohol dependence (Koob, 2008; Roberto et al., 2010; Lowery-Gionta et al., 2012). As the CeA is an integrative hub that coordinates internal and external sensory input into behaviorally relevant responses (Gilpin et al., 2015), the CeA CRF1 system represents a common pathway for the convergence of stress, alcohol, and anxiety-related signaling. Activation of CRF1 has been implicated in the development of the negative emotional state associated with dependence, and it has been proposed that alleviation of this negative state drives the motivation to drink (Koob, 2010). Consistent with this view, administration of a CRF1 antagonist has been shown to reduce ethanol consumption in both rat and mouse models of dependence (Chu et al., 2007; Finn et al., 2007; Funk et al., 2007; Correia et al., 2015). The CRF1 system may also play a critical role in stress-related vulnerability to alcohol exposure. Notably, the increased impulsivity and excessive ethanol consumption in rodents subjected to early life stress can be reversed by CRF1 antagonism as well as pharmacological manipulation of $\mathrm{GABA}_{\mathrm{A}}$ receptor signaling in the CeA (Gondré-Lewis et al., 2016). CRF has been shown to augment GABA transmission in the CeA via actions at CRF1 (Nie et al., 2004; Roberto et al., 2010), and CeA CRF neurons use GABA as a cotransmitter as well as display increased activity after chronic stress (Partridge et al., 2016). It is important to note that the mouse model we used in the present study only reflects neurons that express CRF1 (Justice et al., 2008), and provides no information on CRF peptide actions or circuitry. It is not currently known if the CRF1 + CeA neurons 
in the CRF1:GFP mouse display any overlap with CRF neurons in the CeA. Although progress has been made with reporter mice (Silberman and Winder, 2015), more sophisticated animal models and/or technological approaches are required to more directly pinpoint the intersection of the CRF and CRF1 systems in the CeA.

The primary focus of this study is CRF1 circuitry in the CeA and the effects of acute and chronic ethanol on local inhibition and the dysregulation of CeA CRF1 output. This information is critical to developing an improved understanding of how specific circuits within the CeA are altered following chronic alcohol exposure. The CeA is a heterogeneous nucleus, but recent studies have begun to characterize distinct cell populations and their role in circuits governing specific behaviors. For example, circuitryspecific changes in CeA processing have been implicated in conditioned fear (Haubensak et al., 2010) and in anxiety (Botta et al., 2015). A common theme of these studies is the importance of local inhibitory signaling in the flow of information through distinct circuits. Specific inhibitory microcircuits in the central amygdala govern different aspects of fear learning (Ciocchi et al., 2010), and extrasynaptic inhibition regulates the changes in excitability underlying the encoding of generalized fear or anxiety (Botta et al., 2015). The mechanism of disinhibition that we report here following chronic ethanol exposure has also been reported for engaging specific aspects of amygdala circuitry in fear learning (Wolff et al., 2014). Disinhibition of projection neurons has been implicated in critical circuitry changes related to learning and memory in various brain regions and systems (Letzkus et al., 2015). If the development of alcohol dependence can be conceptualized as a pathological expression of learning, then it is compelling that both processes would use a similar mechanism of disinhibition for the engagement of specific components of circuitry. This view agrees with the current focus on the role of disease-specific alterations in distinct amygdala circuits as major contributing factors in the development of addiction (Koob and Volkow, 2010) and the commonalities between addiction and anxiety (Lüthi and Lüscher, 2014).

\section{References}

Alheid GF, Heimer L (1988) New perspectives in basal forebrain organization of special relevance for neuropsychiatric disorders: the striatopallidal, amygdaloid, and corticopetal components of substantia innominata. Neuroscience 27:1-39. CrossRef Medline

Belelli D, Harrison NL, Maguire J, Macdonald RL, Walker MC, Cope DW (2009) Extrasynaptic GABAA receptors: form, pharmacology, and function. J Neurosci 29:12757-12763. CrossRef Medline

Botta P, Demmou L, Kasugai Y, Markovic M, Xu C, Fadok JP, Lu T, Poe MM, Xu L, Cook JM, Rudolph U, Sah P, Ferraguti F, Lüthi A (2015) Regulating anxiety with extrasynaptic inhibition. Nat Neurosci 18:1493-1500. CrossRef Medline

Chieng BC, Christie MJ, Osborne PB (2006) Characterization of neurons in the rat central nucleus of the amygdala: cellular physiology, morphology, and opioid sensitivity. J Comp Neurol 497:910-927. CrossRef Medline

Chu K, Koob GF, Cole M, Zorrilla EP, Roberts AJ (2007) Dependenceinduced increases in ethanol self-administration in mice are blocked by the CRF1 receptor antagonist antalarmin and by CRF1 receptor knockout. Pharmacol, Biochem, Behav 86:813-821. CrossRef

Ciocchi S, Herry C, Grenier F, Wolff SB, Letzkus JJ, Vlachos I, Ehrlich I, Sprengel R, Deisseroth K, Stadler MB, Müller C, Lüthi A (2010) Encoding of conditioned fear in central amygdala inhibitory circuits. Nature 468:277-282. CrossRef Medline

Correia D, Martynhak BJ, Pereira M, Siba IP, Ribeiro AF, Camarini R, Boerngen-Lacerda R (2015) Reduction of ethanol intake by corticotropin-releasing factor receptor-1 antagonist in "heavy-drinking" mice in a free-choice paradigm. Psychopharmacology 232:2731-2739. CrossRef Medline

Eckardt MJ, File SE, Gessa GL, Grant KA, Guerri C, Hoffman PL, Kalant H,
Koob GF, Li TK, Tabakoff B (1998) Effects of moderate alcohol consumption on the central nervous system. Alcohol Clin Exp Res 22:9981040. CrossRef Medline

Eisenhardt M, Hansson AC, Spanagel R, Bilbao A (2015) Chronic intermittent ethanol exposure in mice leads to an up-regulation of CRH/CRHR1 signaling. Alcohol Clin Exp Res 39:752-762. CrossRef Medline

Finn DA, Snelling C, Fretwell AM, Tanchuck MA, Underwood L, Cole M, Crabbe JC, Roberts AJ (2007) Increased drinking during withdrawal from intermittent ethanol exposure is blocked by the CRF receptor antagonist D-Phe-CRF(12-41). Alcohol Clin Exp Res 31:939-949. CrossRef Medline

Franklin KB, Paxinos G (2008) The mouse brain atlas in stereotaxic coordinates, Ed 3. New York: Elsevier Academic Press.

Funk CK, Zorrilla EP, Lee MJ, Rice KC, Koob GF (2007) Corticotropin-releasing factor 1 antagonists selectively reduce ethanol self-administration in ethanoldependent rats. Biol Psychiatry 61:78-86. CrossRef Medline

Gilpin NW, Herman MA, Roberto M (2015) The central amygdala as an integrative hub for anxiety and alcohol use disorders. Biol Psychiatry 77:859-869. CrossRef Medline

Glykys J, Mody I (2007a) Activation of GABAA receptors: views from outside the synaptic cleft. Neuron 56:763-770. CrossRef Medline

Glykys J, Mody I (2007b) The main source of ambient GABA responsible for tonic inhibition in the mouse hippocampus. J Physiol 582:1163-1178. CrossRef Medline

Gondré-Lewis MC, Warnock KT, Wang H, June HL Jr, Bell KA, Rabe H, Tiruveedhula VV, Cook J, Lüddens H, Aurelian L, June HL Sr (2016) Early life stress is a risk factor for excessive alcohol drinking and impulsivity in adults and is mediated via a CRF/GABA mechanism. Stress 19: 235-247. CrossRef Medline

Haubensak W, Kunwar PS, Cai H, Ciocchi S, Wall NR, Ponnusamy R, Biag J, Dong HW, Deisseroth K, Callaway EM, Fanselow MS, Lüthi A, Anderson DJ (2010) Genetic dissection of an amygdala microcircuit that gates conditioned fear. Nature 468:270-276. CrossRef Medline

Heilig M, Koob GF (2007) A key role for corticotropin-releasing factor in alcohol dependence. Trends Neurosci 30:399-406. CrossRef Medline

Herman MA, Roberto M (2016) Cell-type-specific tonic GABA signaling in the rat central amygdala is selectively altered by acute and chronic ethanol. Addiction Biol 21:72-86. CrossRef

Herman MA, Contet C, Justice NJ, Vale W, Roberto M (2013) Novel subunit-specific tonic GABA currents and differential effects of ethanol in the central amygdala of CRF receptor-1 reporter mice. J Neurosci 33: 3284-3298. CrossRef Medline

Hoffman PL, Tabakoff B (1996) Alcohol dependence: a commentary on mechanisms. Alcohol Alcohol 31:333-340. CrossRef Medline

Justice NJ, Yuan ZF, Sawchenko PE, Vale W (2008) Type 1 corticotropinreleasing factor receptor expression reported in BAC transgenic mice: implications for reconciling ligand-receptor mismatch in the central corticotropin-releasing factor system. J Comp Neurol 511:479-496. CrossRef Medline

Koob GF (2008) A role for brain stress systems in addiction. Neuron 59: 11-34. CrossRef Medline

Koob GF (2010) The role of CRF and CRF-related peptides in the dark side of addiction. Brain Res 1314:3-14. CrossRef Medline

Koob GF, Volkow ND (2010) Neurocircuitry of addiction. Neuropsychopharmacology 35:217-238. CrossRef Medline

Letzkus JJ, Wolff SB, Lüthi A (2015) Disinhibition, a circuit mechanism for associative learning and memory. Neuron 88:264-276. CrossRef Medline

Liang J, Spigelman I, Olsen RW (2009) Tolerance to sedative/hypnotic actions of GABAergic drugs correlates with tolerance to potentiation of extrasynaptic tonic currents of alcohol-dependent rats. J Neurophysiol 102:224-233. CrossRef Medline

Lowery-Gionta EG, Navarro M, Li C, Pleil KE, Rinker JA, Cox BR, Sprow GM, Kash TL, Thiele TE (2012) Corticotropin releasing factor signaling in the central amygdala is recruited during binge-like ethanol consumption in C57BL/6J mice. J Neurosci 32:3405-3413. CrossRef Medline

Lüthi A, Lüscher C (2014) Pathological circuit function underlying addiction and anxiety disorders. Nat Neurosci 17:1635-1643. CrossRef Medline

Nie Z, Schweitzer P, Roberts AJ, Madamba SG, Moore SD, Siggins GR (2004) Ethanol augments GABAergic transmission in the central amygdala via CRF1 receptors. Science 303:1512-1514. CrossRef Medline

Partridge JG, Forcelli PA, Luo R, Cashdan JM, Schulkin J, Valentino RJ, Vicini 
S (2016) Stress increases GABAergic neurotransmission in CRF neurons of the central amygdala and bed nucleus stria terminalis. Neuropharmacology 107:239-250. CrossRef Medline

Pitkänen A, Amaral DG (1994) The distribution of GABAergic cells, fibers, and terminals in the monkey amygdaloid complex: an immunohistochemical and in situ hybridization study. J Neurosci 14:2200-2224. Medline

Roberto M, Madamba SG, Moore SD, Tallent MK, Siggins GR (2003) Ethanol increases GABAergic transmission at both pre- and postsynaptic sites in rat central amygdala neurons. Proc Natl Acad Sci U S A 100:20532058. CrossRef Medline

Roberto M, Madamba SG, Stouffer DG, Parsons LH, Siggins GR (2004) Increased GABA release in the central amygdala of ethanol-dependent rats. J Neurosci 24:10159-10166. CrossRef Medline

Roberto M, Cruz MT, Gilpin NW, Sabino V, Schweitzer P, Bajo M, Cottone P, Madamba SG, Stouffer DG, Zorrilla EP, Koob GF, Siggins GR, Parsons LH (2010) Corticotropin releasing factor-induced amygdala gamma- aminobutyric acid release plays a key role in alcohol dependence. Biol Psychiatry 67:831-839. CrossRef Medline

Semyanov A, Walker MC, Kullmann DM, Silver RA (2004) Tonically active GABA A receptors: modulating gain and maintaining the tone. Trends Neurosci 27:262-269. CrossRef Medline

Silberman Y, Winder DG (2015) Ethanol and corticotropin releasing factor receptor modulation of central amygdala neurocircuitry: an update and future directions. Alcohol 49:179-184. CrossRef Medline

Werner DF, Porcu P, Boyd KN, O’Buckley TK, Carter JM, Kumar S, Morrow AL (2016) Ethanol-induced GABAA receptor alpha4 subunit plasticity involves phosphorylation and neuroactive steroids. Mol Cell Neurosci 72:1-8. CrossRef Medline

Wolff SB, Gründemann J, Tovote P, Krabbe S, Jacobson GA, Müller C, Herry C, Ehrlich I, Friedrich RW, Letzkus JJ, Lüthi A (2014) Amygdala interneuron subtypes control fear learning through disinhibition. Nature 509:453-458. CrossRef Medline 